\title{
ARCHEOLOGICKÉ PROJEVY STŘEDOVĚKÉ A RANĚ NOVOVĚKÉ NEZDĚNÉ ZÁSTAVBY NA PARCELÁCH NĚKDEJŠÍCH DOMŮ Č. 6 A 8 NA VÍDEŇSKÉ ULICI V BRNĚ
}

\author{
ANTONÍN ZŮBEK
}

\begin{abstract}
Abstrakt: Přispěvek shrnuje poznatky o středověké a raně novověké zástavbě na parcelách někdejšich domů č. 6 a 8 na Vídeňské ulici v Brně, která sestávala zřejmě především z nezděných (dřevěných nebo dřevohliněných) staveb. Jeji archeologizované pozůstatky byly zkoumány při záchranném archeologickém výzkumu, který v roce 2013 realizovala společnost Archaia Brno, o.p. s. Jednotlivé objekty jsou popsány a podle společných znaků kategorizovány do přislušných skupin. Součástí př́spěvku je i jejich základní srovnání s archeologickými projevy drevohliněné zástavby na dalšich lokalitách užšiho brněnského prostoru.
\end{abstract}

Klíčová slova: středověk - novověk - Brno-předměstí-zástavba.

Archaeological evidence of medieval and early modern age non-masonry construction on the plots of former houses nos. 6 and 8 in Vídeňská Street, Brno

Abstract: This contribution sums up information about the medieval and early modern age construction on the plots of former houses nos. 6 and 8 in Videňská Street, Brno which probably mostly consisted of non-masonry (timber or timber-earth) structures. Their archaeological remains were investigated during rescue research conducted in 2013 by the Archaia Brno company. The individual structures are described and classified into groups based on their common features. The article also involves their basic comparison with archaeological evidence of timber-earth constructions in other locations of the inner city.

Key words: Middle Ages - modern age - Brno - suburb - construction.

\section{1 Úvod}

Cílem př́íspěvku je shrnout poznatky o středověké a raně novověké zástavbě na parcelách někdejších domů č. 6 a 8 na Vídeňské ulici v Brně. Zástavba v tomto období sestávala zřejmě především z nezděných (dřevěných nebo dřevohliněných) staveb. Její archeologizované pozůstatky byly zkoumány při záchranném archeologickém výzkumu, který v roce 2013 realizovala společnost Archaia Brno, o.p.s. (akce č. A113/2012 - Černá-Zůbek 2017; Černá a kol. 2014, 194). Jednotlivé objekty budou charakterizovány a podle společných znaků kategorizovány do příslušných skupin. Součástí příspěvku je rovněž jejich srovnání s archeologickými projevy dřevohliněné zástavby na dalších lokalitách užšího brněnského prostoru. Počet takových objektů za poslední dvě desetiletí narostl díky systematické realizaci záchranných archeologických výzkumů při většině stavebních počinů. Zcela ojedinělý je v tomto ohledu prostor vlastního městského jádra (k systematickému výzkumu Brna viz Holub a kol. 2004; poslední souhrnné zpracování nezděné architektury Holub a kol. 2005). Řada reliktů nezděné zástavby byla dále dokumentována při výzkumech v historické části Králova Pole (dnes součást Brna).

Nabízí se možnost porovnat archeologický odraz nezděné zástavby ze tř̌́ typově odlišných lokalit. Na jedné straně stojí samotné město, sídelní centrum kraje, na straně druhé sídelní celky z jeho bezprostředního okolí. Ves Královo Pole, ač již poměrně vzdálena (ca $3 \mathrm{~km}$ ), se vyznačovala těsnými vztahy k městu, kterými se vykazují předměstí. Byla vysazena zřejmě ve 40 . letech 13. století králem Václavem I. v součinnosti s brněnskými měštany. K založení posloužilo „královo pole“ příslušné patrně k zeměpanskému hospodářskému dvoru. Zeměpanský díl se choval k městu jako předměstí, jeho obyvatelé přispívali na městskou sbírku. Správu vykonával rychtář s př́ísežnými (ve stručné podobě Procházka-Kolařík-Zůbek 2013, 585-586; ke středověkým dějinám Králova Pole viz Jan 2004). Parcely na dnešní Vídeňské ulici náležely k osadě (asi $1 \mathrm{~km}$ od města), která se utvořila podél dálkové komunikace spojující brněnskou oblast s Rakouskem. Byla součástí Starého Brna, někdejšího mocenského centra, které se transformovalo do útvaru, jejž lze označit jako poddanské městečko (viz následující oddíl). 


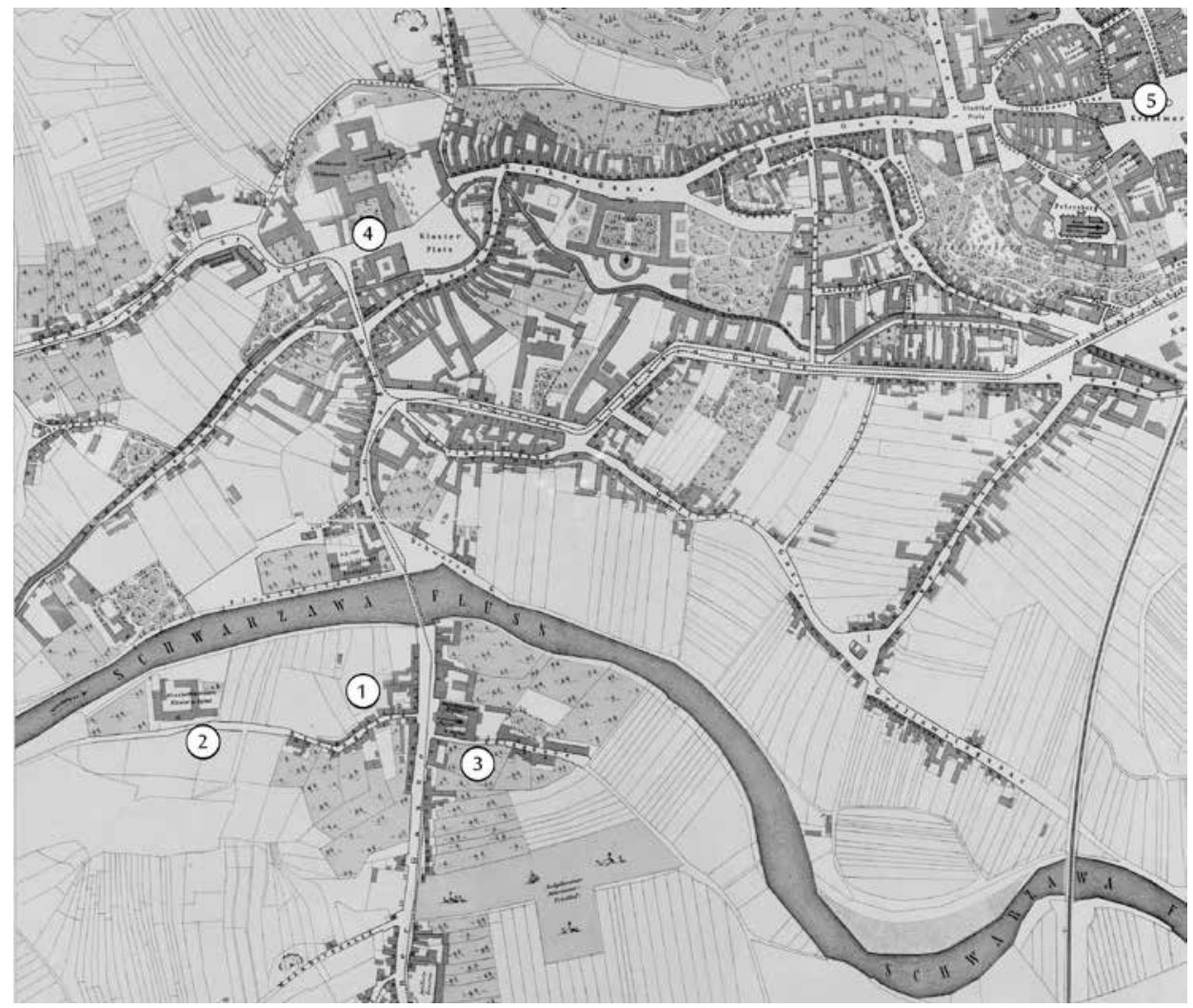

Obr. 1. Výřez plánu z roku 1885 s územím Starého Brna (Archiv města Brna, fond U 9, sign. K42). Č́́sla v bílých kroužcích: 1 - poloha archeologického výzkumu, 2 - konvent alžbětinek, 3 - konvent milosrdných bratří, 4 - centrum Starého Brna s radnicí a klášterem cisterciaček, 5 - historické jádro města Brna.

Abb. 1. Ausschnitt aus einem Plan von 1885 mit dem Gebiet von Altbrünn (Archiv der Stadt Brno, Bestand U 9, Sign. K42). Ziffern in weißen Kreisen: 1 - Lage der archäologischen Grabung, 2 - Elisabethinen-Konvent, 3 - Konvent der Barmherzigen Brüder, 4 - Zentrum von Altbrünn mit Rathaus und Zisterzienserinnenkloster, 5 - historischer Stadtkern von Brünn.

\section{Historicko-topografický kontext}

Zkoumaná plocha parcel někdejších domů č. 6 a 8 na Vídeňské ulici je dnes součástí katastrálního území Štýřice. Jde o parcelu č. 687/1 a př́íslušná novostavba nese označení 1021/6 (obr. 2). Nově vymezený pozemek sloučil někdejší parcely č. 687/1, 688/1 až 5 a 690. Jako katastrální území vznikly Štýřice až při radikální katastrální reformě Brna na konci 60. let 20. století. Vyčleněno bylo z jižní části někdejšího katastrálního celku Staré Brno a Vídeňka a připojeny k němu byly okrajové části sousedních katastrů Bohunic, Horních Heršpic, Komárova, Nových Sadů a Trnité. Název nového katastrálního území byl převzat od zaniklé vsi, která se nacházela jihovýchodním směrem u Horních Heršpic (zanikla zřejmě v 15. století - Dřímal 1973, 303-304). Původně byly zmíněné parcely součástí Starého Brna. Náležely do jeho jižní partie na pravém břehu řeky Svratky.

Zkoumaný prostor se nachází na úpatí svahu Červeného kopce v blízkosti řeky Svratky. Červený kopec představuje výrazný geomorfologický prvek kraje $(311 \mathrm{~m}$ n. m.) a zaujímá v něm poměrně strategickou polohu. Vzdálenost plochy $\mathrm{k}$ dnešnímu regulovanému říčnímu toku činí $100 \mathrm{~m}$. Jednalo se o poměrně př́iznivé místo k osídlení. To se obecně týká také území v širším 


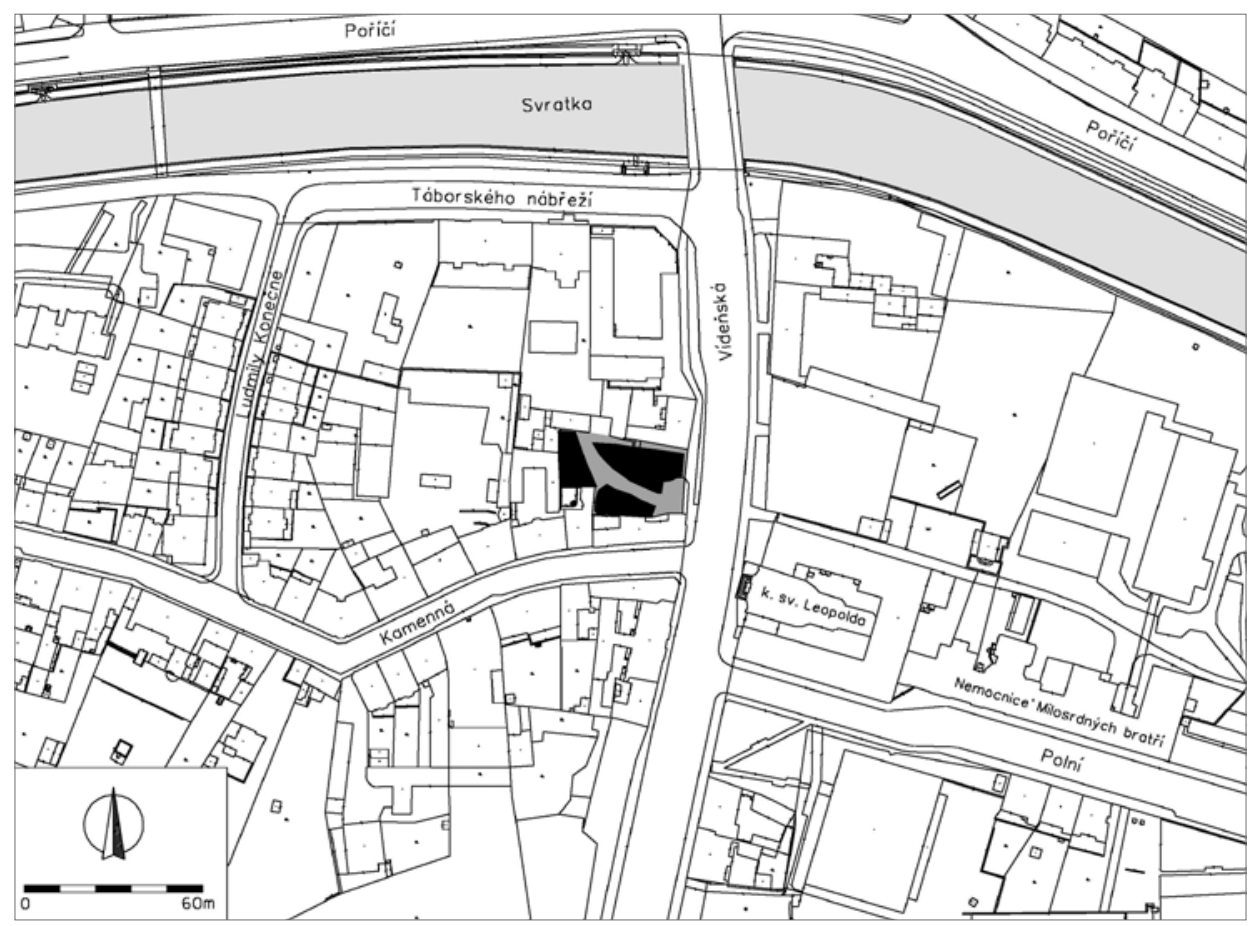

Obr. 2. Poloha archeologického výzkumu. Šedě vyznačen rozsah staveniště, černě zkoumané plochy.

Abb. 2. Lage der archäologischen Grabung. Grau gekennzeichnet ist das Ausmaß der Baustelle, rot die untersuchten Flächen.

sousedství. Od západu bylo chráněno dominantou Červeného kopce, důležitá byla blízkost vodního zdroje. Navíc ohyb řeky zpomalující její tok v tomto prostoru zřejmě představoval př́hodné místo k jejímu překročení. Přemostění řeky zde máme doloženo od vrcholného středověku až do dnešních dnů (Flodrová-Müller 2007, 203-204). Př́ihodných podmínek lokality využili již lidé v pozdní fázi mladého paleolitu (aktuální zpracování tématu se souhrnem dosavadního bádáníNerudová 2016). K osídlování území docházelo rovněž v mladších údobích pravěku - neolitu, eneolitu, době bronzové a starší době železné (téma zatím souhrnněji nezpracováno - informace lze čerpat především z nálezových zpráv, např. Černá-Sedláčková 2016; 2016a; Matějíčková 1999; Polánka-Sedláčková-Zůbek 2006; Sedláčková 2012; 2012a; Zapletalová 1999; 2005).

Sídelně atraktivní zůstalo území rovněž v období raného stř̌edověku. Přesvědčivé doklady osídlení z jeho prvotních fází nebyly dosud získány. Nejstarší známé nálezy patří do přelomu starší a střední doby hradištní a pocházejí z poněkud vzdálenějšího místa jihovýchodním směrem při křižovatce Grmelovy a Vojtovy ulice. Zřejmě do druhé poloviny 9. století je možné datovat hroby nalezené pod severním křídlem kláštera Milosrdných bratří, které svědčí o existenci nekropole v těchto místech. Sídlištní situace z 9. a 10. století byly zaznamenány na svrateckém levobřeží. Severněji, v pozdějším areálu starobrněnského kláštera na Mendlově náměstí v této době patrně fungovalo další pohřebiště (nejnověji souhrnně se starší literaturou ProcházkaWihoda-Zapletalová 2011, 488-490).

Archeologické doklady osídlení se zintenzivňují v mladohradištním období. Týká se to celé oblasti zahrnující jak levobřeží, tak pravobřeží Svratky. Lze předpokládat, že dochází ke změnám v sídelní struktuře a mění se také význam prostoru minimálně v mladší fázi této epochy. Do ostrovní polohy mezi řekou a jejím severněji tekoucím vedlejším ramenem (pozdější 
Svratecký náhon) bývá situován hrad brněnských knížat. Osídlena byla i jeho předpolí, severní za Svrateckým náhonem a jižní na pravém břehu Svratky. Na obou byla zaregistrována pohřebiště s rotundou (nejnověji k problematice Kolařík-Merta-Zůbek 2014; Merta-Sedláčková 2013; Procházka-Wihoda-Zapletalová 2011, 515-522; Zapletalová 2009). Tato sídlištní aglomerace tvořící mocenské centrum knížectví se stala $\mathrm{v}$ závěru raného středověku ústředním sídelním útvarem oblasti.

Velké změny přicházejí s nástupem vrcholného středověku. Dominantním prvkem kraje se postupně stává město Brno, které se začalo rozvíjet od přelomu 12. a 13. století. Starobrněnský prostor s někdejším hradem ustoupil do pozadí. Stává se součástí sídelní struktury v blízkém sousedství města. Ve vrcholném středověku představovalo Staré Brno obtížně zařaditelný útvar s vlastním rychtářem a blížilo se postavení městečka (k problematice Doležel 2000, 172-175; stručně Procházka-Kolařík-Zůbek 2013, 558-568; obecně k dějinám Starého Brna FlodrováMüller 2007; Kuča 2000, 518-535).

Na pravém břehu Svratky existovala osada, jejíž zástavba se koncentrovala podél komunikace směřující ze Starého Brna $\mathrm{k}$ jihu. Byla předchůdkyní císařské silnice do Vídně z roku 1727 (ke komunikačnímu schématu Starého Brna na pravobřežní Svratky v období středověku a novověku Urbánková-Zapletalová 2003). Dnes jde o jednu z páteřních komunikací města. Od roku 1867 nese název Vídeňská ulice (Wiener Strasse, v letech 1946-1990 Koněvova ulice Flodrová 1997, 267). Stávala zde mýtnice a některými historiky sem byl situován výstavný „Kamenný “ dvůr cisterciáckého kláštera na Starém Brně, zmíněný v pramenech například v letech 1330 a 1383 (Doležel 2000, 173; Flodrová-Müller 2007, 228). Zástavba je poprvé vyobrazena na ikonografických materiálech z poloviny 17. století (poněkud idealizovaně na rytině z knihy Topographia Bohemiae, Moraviae et Silesiae, vydané roku 1650 - viz citace Merian 1650; realističtěji na obraze H. B. Beyera a H. J. Zeisera Obléháni Brna Švédy roku 1645 z doby okolo poloviny 17. století - uložen v Muzeu města Brna, inv. č. 2284). Její průběžný vývoj lze do jisté míry sledovat na plánech z následujícího období 18. až 20. století. Výraznými objekty se před polovinou 18. století staly budovy dvou nově založených klášterů. V roce 1747 byl fundován konvent milosrdných bratří s kostelem sv. Leopolda a s nemocnicí (dnes Vídeňská 7, Polní 1/3 - Foltýn a kol. 2005, 218-222), o dva roky později konvent Alžbětinek s kaplí sv. Alžběty Durynské a s nemocnicí (dnes Kamenná 36 - Foltýn a kol. 2005, 222-225).

Domy, na jejichž parcelách byl realizován archeologický výzkum, byly po zavedení orientačních čísel v roce 1867 označeny jako 6 a 8 , na mapách z první poloviny 19. století byly popsány jako 84 a 83b (viz např. katastrální mapa z let 1840-1841 - Archiv města Brna, fond U 9, sign. KAT. 154).

\section{Archeologický výzkum}

Záchranný archeologický výzkum na parcelách někdejších domů Vídeňská 6 a 8 byl vyvolán výstavbou nového multifunkčního objektu. Realizován byl v jarních měsících roku 2013. Byl jediným archeologickým počinem, který se na parcelách uskutečnil. Po dohodě se stavebníkem měl být výzkum rozdělen do dvou základních fází. První fáze předcházela vlastním stavebním pracím. Stavebníkem byly určeny plochy, na kterých bylo možné v této fázi provést exkavaci. V podstatě se jednalo o tři základní celky. Pro potřeby archeologického výzkumu byly označeny jako plocha A, plocha $\mathrm{B}+\mathrm{C}+\mathrm{D}$ a plocha $\mathrm{E}$. Musely být zachovány bloky zeminy při okolní zástavbě, aby nedošlo k narušení její statiky. Ponechána zůstala komunikace procházející parcelami úhlopříčně od jihovýchodu na severozápad. Zčásti vedla nad trasou teplovodu, při jehož výstavbě byla v minulosti zničena značná část archeologických situací. Průběh teplovodu měl tvar písmene L. Jeho kratší rameno procházelo středem plochy B, delší zasahovalo do jižní partie plochy C.

Na zkoumaných plochách proběhlo odtěžení novodobých navážek mechanizací. Následovala exkavace a dokumentace přitomných archeologických situací. Většinou šlo o do podloží zahloubené objekty a jejich výplně. Výzkum dolních partií nejhlubších situací, které nebylo 


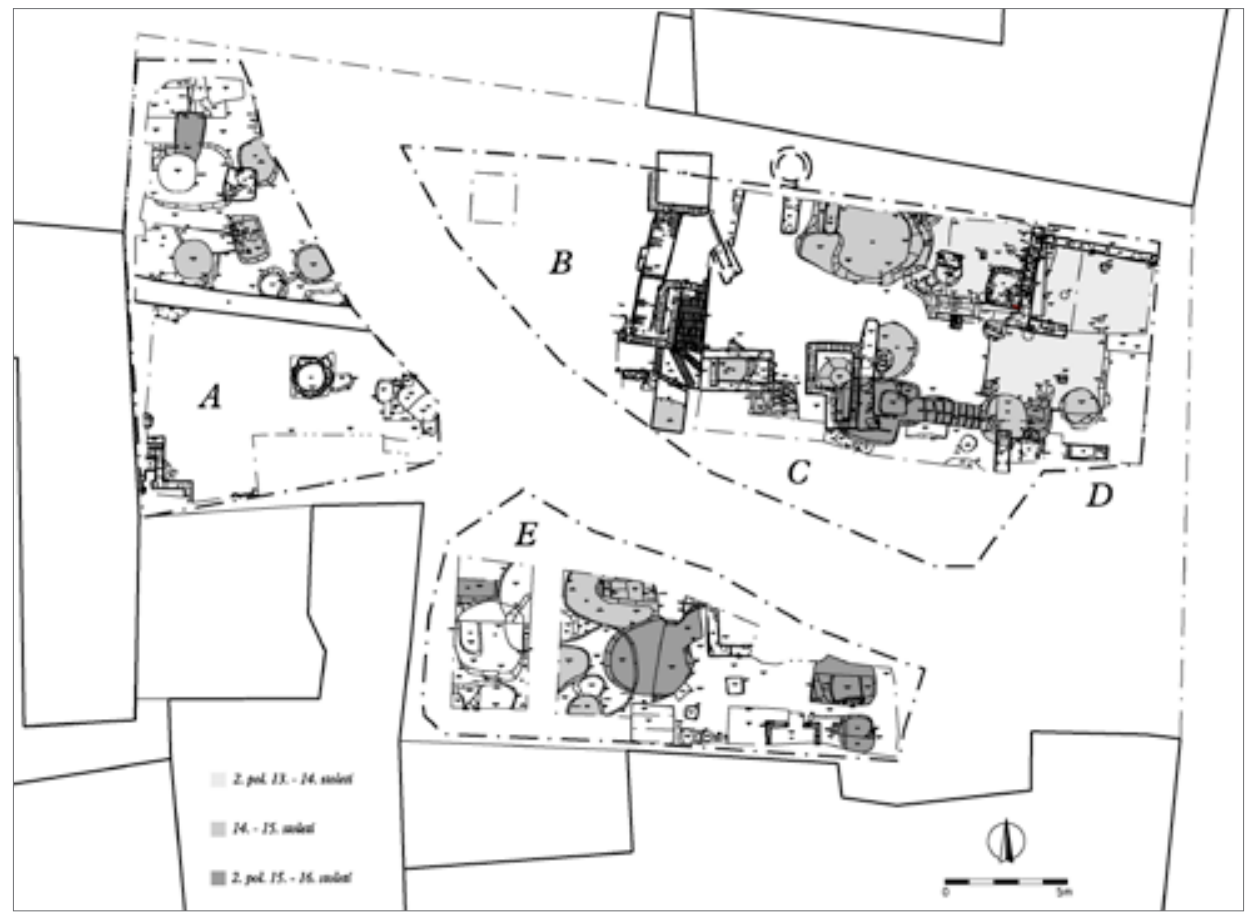

Obr. 3. Přehled zkoumaných situací z 13.-20. století. Světle šedou barvou podbarveny aktivity z druhé poloviny 13.-14. století, středně šedou ze 14.-15. století, tmavě šedou z druhé poloviny 15.-16. století.

Abb. 3. Übersicht der untersuchten Situationen aus dem 13. bis 20. Jahrhundert. Hellgrau untermalt - Aktivitäten aus der zweiten Hälfte des 13. bis 14. Jahrhunderts, mittelgrau 14. bis 15. Jahrhundert, dunkelgrau zweite Hälfte 15. bis 16. Jahrhundert.

možné z bezpečnostních důvodů archeologicky dotěžit, byl plánován do následující fáze výzkumu, která již měla probíhat v součinnosti se stavebními pracemi.

Druhá fáze výzkumu měla následovat po statickém zajištění obvodových stěn stavební jámy. Mělo dojít k exkavaci archeologických situací na dosud nedotčených plochách. Při následném hloubení stavební jámy pak měly být dozkoumány nejhlubší výkopy. Druhá fáze výzkumu se ovšem neuskutečnila, protože stavebník svévolně dotěžil stavební jámu bez jakéhokoliv dalšího archeologického počinu. Svým způsobem tak lze archeologickou akci označit za předstihový sondážní výzkum předmětných parcel, jejichž celkovou archeologickou exkavaci se nepodařilo uskutečnit. Staveniště mělo rozsah $1000 \mathrm{~m}^{2}$. Archeologická exkavace se odehrála na třech dílčích plochách o celkové výměře $600 \mathrm{~m}^{2}$.

\section{Nálezová situace}

Svrchní část geologického podloží tvoří kvartérní souvrství sestávající z eolických, deluviofluviálních a fluviálních sedimentů. Fluviální sedimenty jsou složeny ze spodního souvrství terasových písčitých štěrků a písků a svrchního souvrství písků a povodňových hlín. V nadloží fluviálních sedimentů jsou vyvinuty náplavové písčité hlíny a sprašové hlíny o relativně nevelké mocnosti. Půdní horizont nebyl na zkoumané ploše př́itomen. Na povrch podloží dosedala uloženina, kterou je možné na základě vyhodnocení stratigrafické situace a získaného mobiliáře zasadit do období 18.-19. století. Interpretovat ji lze jako navážku, která zároveň utvářela „zahradní vrstvu“. Otázky, kdy přesně a jakým způsobem došlo k odstranění půdního horizontu 


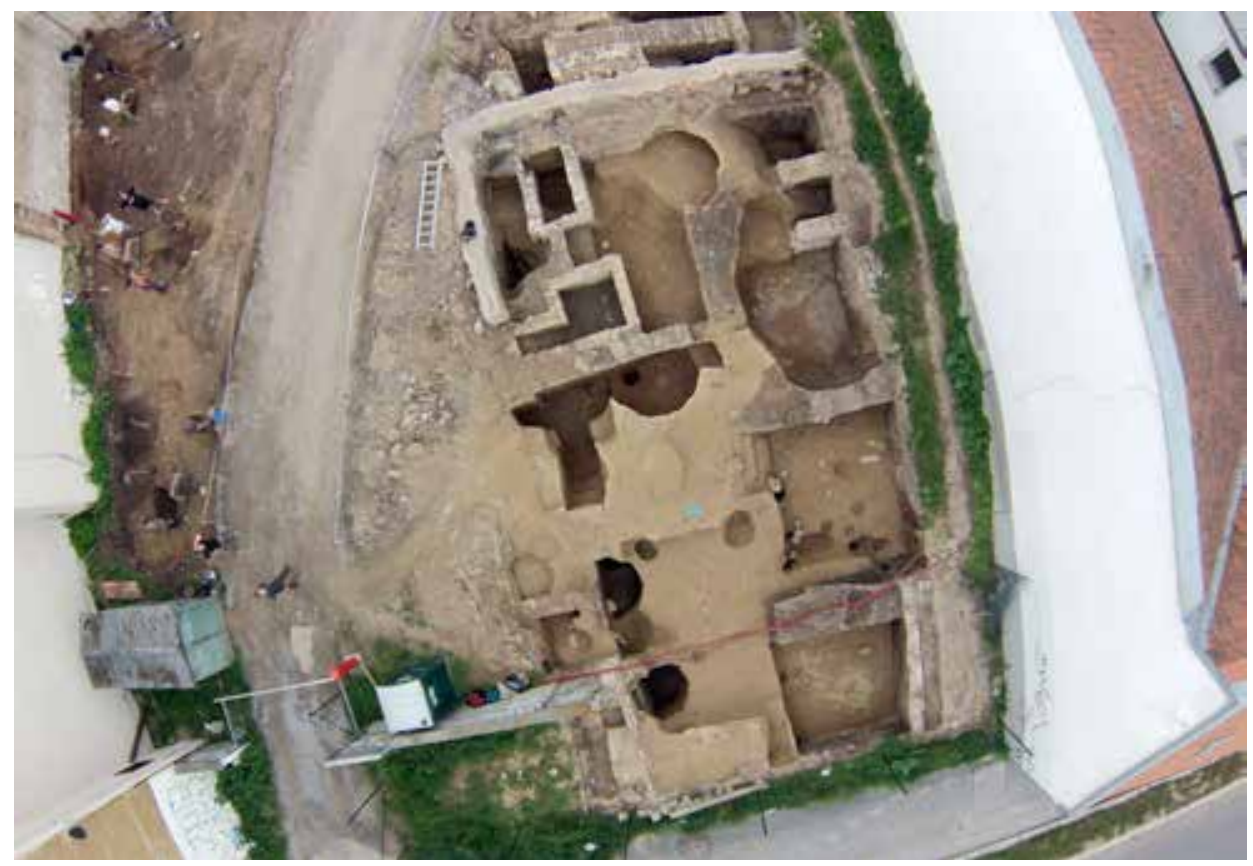

Obr. 4. Pohled na dokopanou úroveň plochy $\mathrm{C}$ a $\mathrm{D}$ (orientováno $\mathrm{k}$ západu), na němž jsou patrné relikty dř̌vohliněné zástavby. Vlevo probíhá exkavace situací na ploše E. Zdroj fotoarchiv Archaia Brno, o.p.s.

Abb. 4. Blick auf das ausgehobene Niveau der Flächen C und D (nach Westen orientiert), auf welcher Relikte einer Holz-Lehm-Bebauung zu erkennen sind. Links erfolgt eine Freilegung der Situation auf Fläche E. Quelle Fotoarchiv Archaia Brno, o.p.s.

a př́ípadně dalších podložních vrstev, se nepodařilo při výzkumu zodpovědět. Pravděpodobně se však jedná o výsledek lidské činnosti. V této souvislosti je zajímavá skutečnost, že na sousední parcele domu Kamenná 4 byl půdní horizont zachován (dosahoval mocnosti 0,5 m - Nerudová 2016, 130). Starší aktivity než jmenovaná vrstva z 18.-19. století představovaly výhradně zahloubené objekty.

Projevy středověké a novověké zástavby byly omezeny pouze na její výrazněji zahloubené části (přehledový plán - obr. 3). Kromě možných reliktů nadzemních partií staveb (např. podlahové vrstvy) chyběly také př́ípadné doklady zahloubených částí jejich nadzemních konstrukcí (např. sloupových a kůlových jamek, žlábků pro usazení základových trámů). Registrováno bylo třináct, popř́ípadě dvanáct situací (s. s. j. 049 a 050 by mohly náležet jednomu objektu), které je možné s nezděnou zástavbou spojovat. ${ }^{1}$ Jejich datování bylo provedeno na základě rozboru stratigrafické situace a materiálu získaného z výplní. Většinou šlo o soubory zlomků keramických nádob, v několika případech doplněné nálezy mincí. ${ }^{2}$

\section{Popis objektů}

\section{S. s.j. 003}

Suterén stavby (obr. 5 a 7). Byl utvořen pravidelným výkopem čtvercového nebo obdélného půdorysu (s. j. 560). Stěny výkopu byly přímé, svislé nebo strmě šikmé, dno ploché.

1 S. s. j. - svazek stratigrafických jednotek. Podle užité metodiky zahrnuje jeden svazek aktivity, které spolu souvisejí a často vytvářeji vyšší celek. Pro jednotlivé aktivity se uživá termín stratigrafická jednotka (zkratka s. j.).

2 Určení mincí provedl Mgr. Kamil Smišek (2018). 

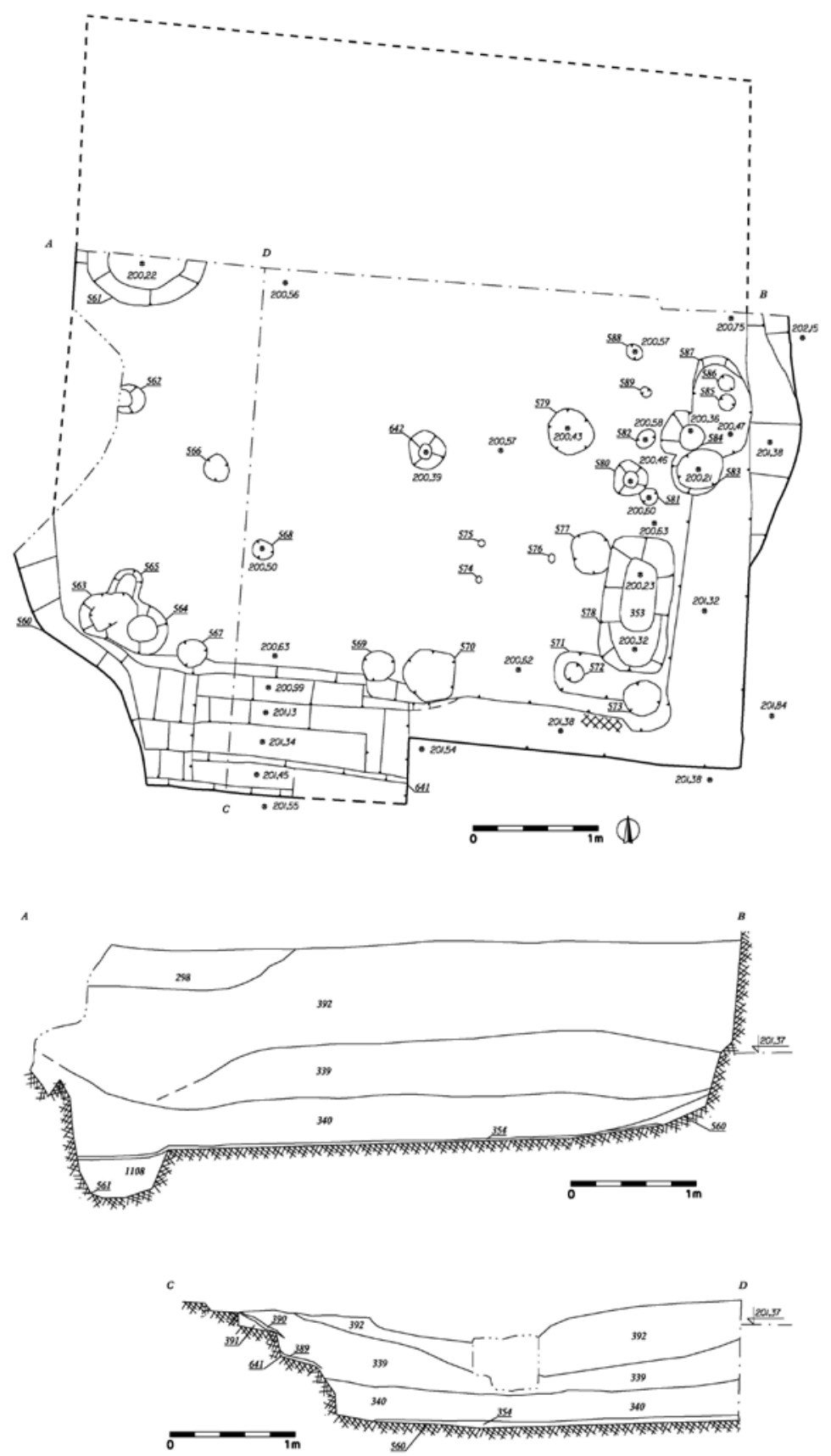

Obr. 5. Objekt s. s. j. 003 - půdorys a profily. 561-589, 642 - výkopy kůlových a sloupových jamek; 354 - nášlapová vrstvička; 340 - vrstva odpadního charakteru; 339 - zřejmě hliněná složka destruované konstrukce stavby; 392 - zásypová vrstva s jistým podílem požárové složky.

Abb. 5. Objekt Verband stratigraphischer Einheiten 003 - Grundriss und Profile. 561 - 589, 642 - ausgehobene Pfahl- und Pfeilergruben; 354 - Gehschicht; 340 - Schicht mit Abfallcharakter; 339 - offenbar Lehmkomponente einer zerstörten Baukonstruktion; 392 - Verfüllungsschicht mit gewissem Anteil einer Brandkomponente. 

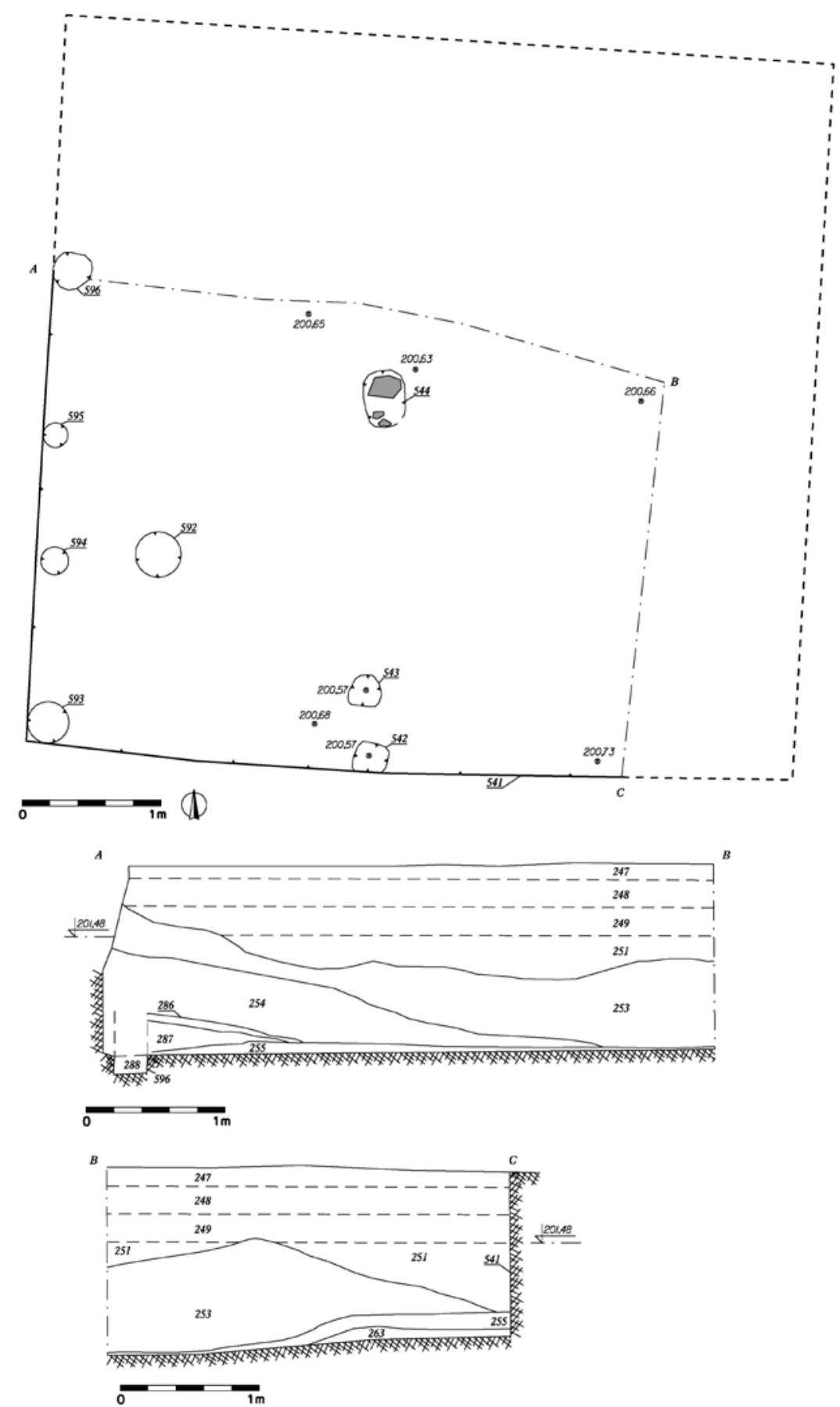

Obr. 6. Objekt s. s. j. 004 - půdorys a profily. 542-544, 593-596 - výkopy kůlových a sloupových jamek; 247-249, 251, 254 tmavě hnědá hlína; 253 - okrový písek.

Abb. 6. Objekt Verband stratigraphischer Einheiten 004 - Grundriss und Profile. 542 - 544, 593 - 596 - ausgehobene Pfahlund Pfeilergruben; 247-249, 251, 254 - dunkelbrauner Lehm; 253 - ockerfarbener Sand. 


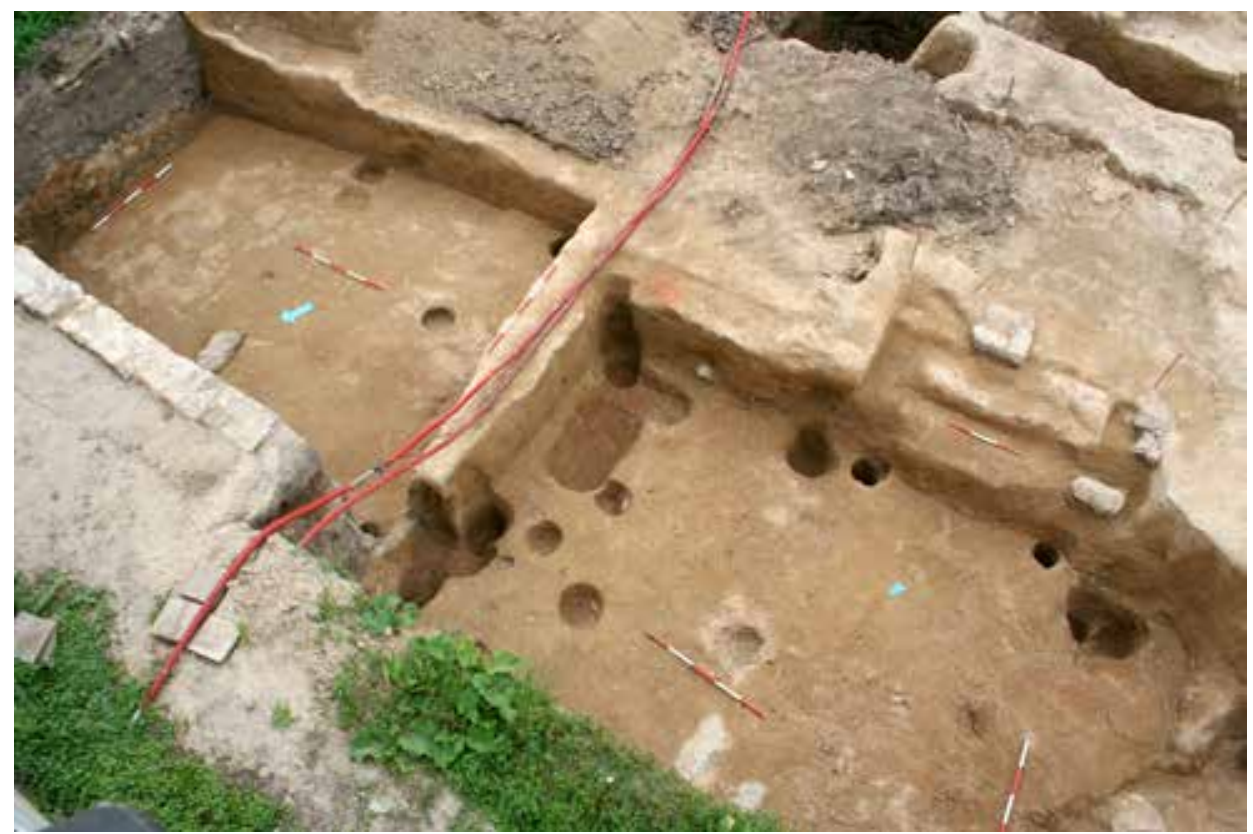

Obr. 7. Pohled od severozápadu na objekty s. s. j. 003 a 004. Zdroj fotoarchiv Archaia Brno, o.p. s. - foto č. 9092-2013. Abb. 7. Blick aus Nordwesten auf die Objekte Verband stratigraphischer Einheiten 003 und 004. Quelle Fotoarchiv Archaia Brno, o.p.s. - Foto Nr. 9092-2013.

V jihovýchodním rohu byly stěny výkopu ve výšce $0,7 \mathrm{~m}$ nade dnem odsazeny o 0,3 až $0,6 \mathrm{~m}$. Účel lze snad spatřovat $\mathrm{v}$ uložení trámů, které se mohly podílet na založení konstrukce nadzemní části příslušné stavby. V jihozápadním rohu se nacházela vstupní část, utvořená výkopem s. j. 641. Př́íslušné schodiště mělo zřejmě dřevěnou konstrukci opřenou do stupňovitého dna výkopu. Po stranách byly žlábky patrně určené pro podélné prvky schodiště (trámy), mezi něž byly nejspíš osazeny desky vlastních schodů. Sloupové a kůlové jamky dokládají dřevěnou konstrukci stěn suterénu. Několik sloupových jamek bylo zaznamenáno rovněž v jeho ploše. Podílely se zřejmě na zajištění stropu, popřípadě náležely konstrukcím, které suterén členily. S užíváním sklepa souvisí několik drobných kůlových jamek (s. j. 574-576). Na dně se utvořila komunikační (nášlapová) vrstvička (s. j. 354). Na ní ležela vrstva s. j. 340 odpadního charakteru, následovala s. j. 339, kterou lze považovat za hliněnou součást konstrukce stavby. Tato skutečnost by prokazovala to, že přináležející stavba nezanikla požárem. Stopy ohně v podobě dílčího propálení malé partie jižní stěny suterénu byly zaznamenány při jihovýchodním rohu. Nelze však zcela vyloučit možnost, že šlo o pozůstatek starší aktivity, kterou výkop suterénu narušil. Doklady požáru v podobě zlomků vypálené mazanice byly výrazněji (ca $30 \%$ ) zastoupeny pouze v horní části výplně (s. j. 392). Vnitřní světlost sklepa činila $4 \times>3,2 \mathrm{~m}$. Hluboký byl minimálně 1,6 m. Šírka vstupního schodiště činila ca $1,4 \mathrm{~m}$. Keramické zlomky nalezené v nášlapové vrstvě na dně suterénu lze datovat do období od druhé poloviny 13. do 14. století. Stejně datovatelný soubor fragmentů kuchyňské keramiky byl získán také z následující vrstvy (s. j. 340). Obsahovala rovněž minci, která určuje terminus post quem. Jde o stř́ibrný parvus Václava II. (1283-1305), ražený v Kutné Hoře v letech 1300-1305. Materiál z dalších výplní suterénu je možné zařadit do druhé poloviny 14. až první poloviny 15 . století. Tuto skutečnost by bylo možné vysvětlit tak, že suterén měl dvě základní fáze vývoje. Vrstva s. j. 340 by představovala zvýšení jeho podlahové úrovně o $0,3 \mathrm{~m}$. Přesný účel tohoto zvýšení nebyl určen. Snad by se mohlo jednat o izolační 

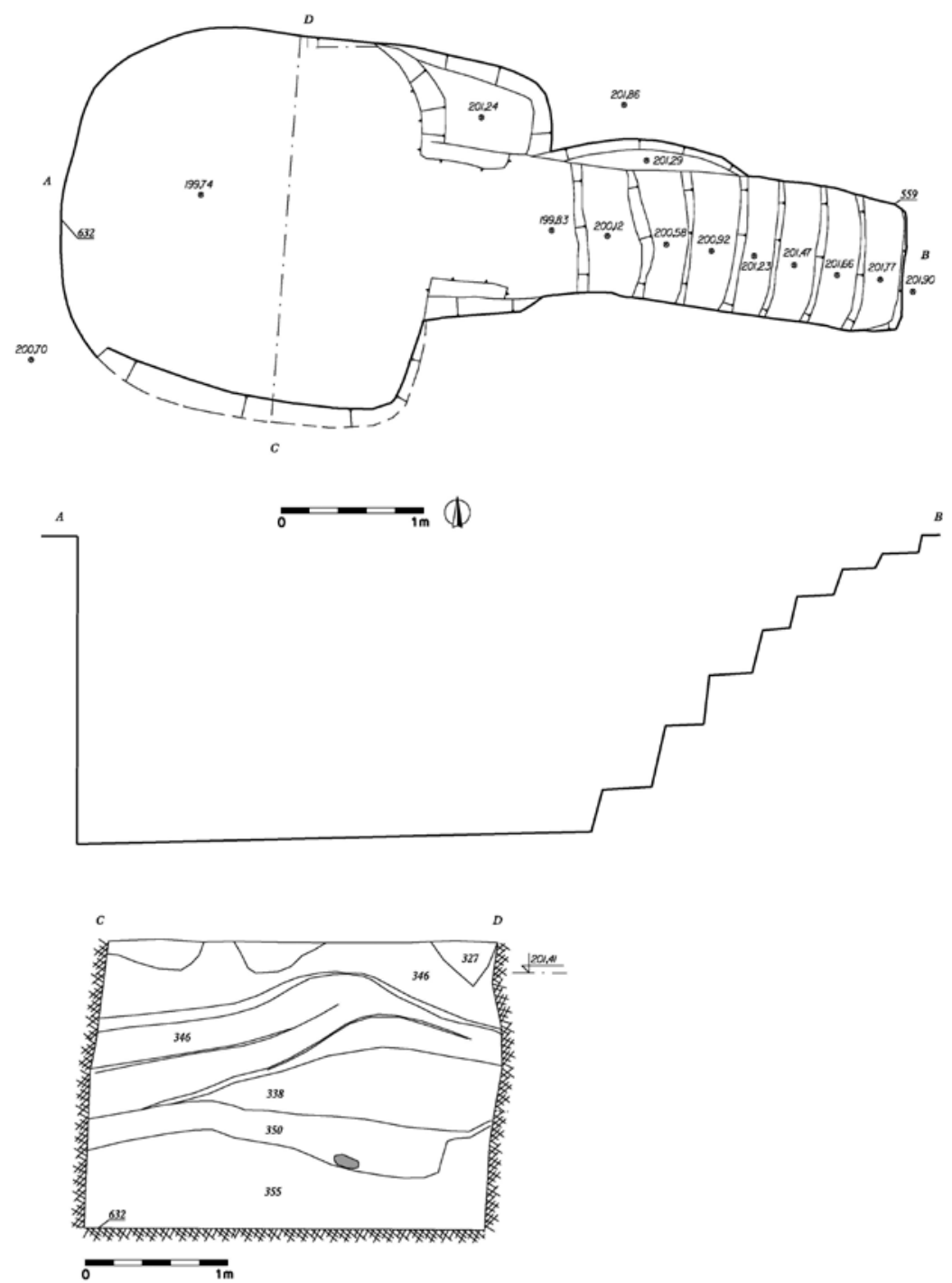

Obr. 8. Objekt s. s. j. 005 - půdorys a profily. 355 - zřejmě spadený strop; 338, 346, 350 - zásypové vrstvy.

Abb. 8. Objekt Verband stratigraphischer Einheiten 005 - Grundriss und Profile; 355 - offenbar eingestürzte Decke; 338 , 346,350 - Verfüllungsschichten.

vrstvu proti vlhkosti stoupající z původní podlahy. Suterén byl stratigraficky mladší než suterén s. s. j. 004 a starší než situace s. s. j. 047.

S. s.j. 004

Suterén stavby (obr. 6 a 7). Byl utvořen pravidelným výkopem čtvercového nebo obdélného půdorysu (s. j. 541). Stěny výkopu byly přímé, svislé, dno ploché. Sloupové a kůlové jamky dokládají dřevěnou konstrukci stěn suterénu. Několik jamek bylo zaznamenáno rovněž v ploše sklepa. Podílely se zřejmě na zajištění stropu, poprŕípadě náležely konstrukcím, které 


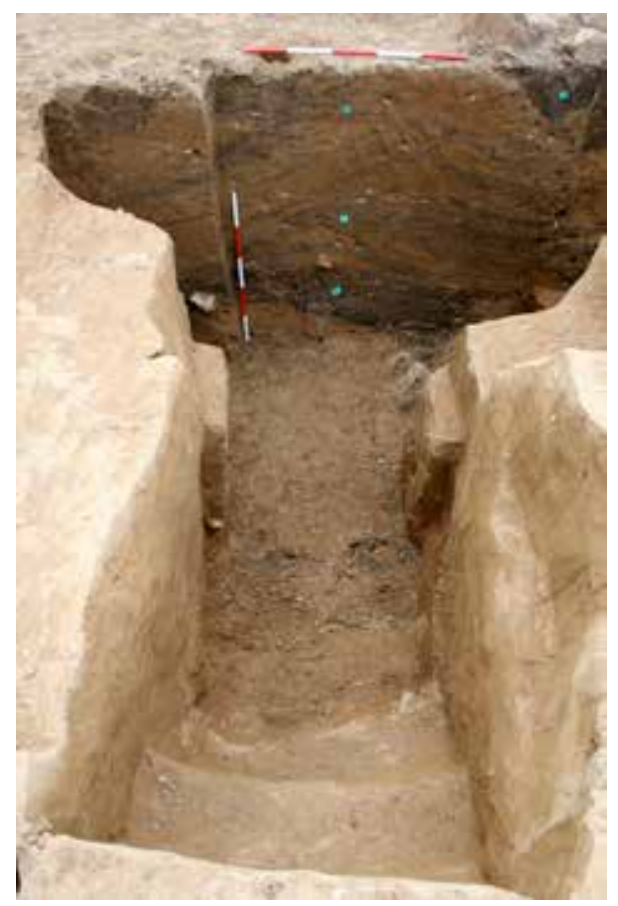

Obr. 9. Pohled od východu na vstupní část do objektu s. s. j. 005. Zdroj fotoarchiv Archaia Brno, o.p.s. - foto č. 9031-2013.

Abb. 9. Blick aus Osten auf den Eingangsteil in Objekt Verband stratigraphischer Einheiten 005. Quelle Fotoarchiv Archaia Brno, o.p.s. - Foto Nr. 9031-2013. suterén členily. Na dně se utvořila komunikační (nášlapová) vrstvička (s. j. 255). Suterén a př́slušná stavba nezanikly požárem. Došlo patrně k řízené destrukci a zasypání suterénu. Ze situace na profilu P24 lze usuzovat, že dřevěná konstrukce stěn suterénu nebyla alespoň zčásti odstrojena. K zaplnění byl pravděpodobně použit těžený materiál. Jeho dominantní část měla stejný charakter jako dokumentované výplně objektů z 11.-12. století (s. j. 247-249, 251, 254). Jeho součástí byl poměrně četný soubor keramických zlomků z tohoto období. V př́ípadě výplně s. j. 253 by mohlo jít o přemístěné podloží (okrový písek). Zcela však nelze vyloučit možnost, že šlo o hliněnou složku konstrukce. Vnitřní světlost sklepa činila $>4,2 \times>3,3 \mathrm{~m}$. Hluboký byl minimálně $1,5 \mathrm{~m}$. Př́ípadná vstupní část nebyla na zkoumané ploše zaregistrována. Nejmladší keramický materiál získaný z výplní lze datovat do období od druhé poloviny 13. do 14. století. Suterén byl stratigraficky mladší než suterén s. s. j. 006 a starší než s. s. j. 003.

\section{S. s.j. 005}

Sklípek (obr. 8 a 9). Pravděpodobně vznikl ražbou do podložních vrstev (část výkopu s. j. 632). Vrstva s. j. 355 na jeho dně by pak představovala spadený strop. Zcela vyloučit ovšem nelze možnost, že šlo o hliněnou složku konstrukce příslušné stavby a sklípek byl kopaný shora. Další výplně měly poměrně jednoznačný zásypový charakter. Sklípek byl př́ístupný schodištěm od východu, jež bylo utvořeno výkopem s. j. 559, který měl prrímé, svislé stěny a stupňovitě tvarované dno. Zachováno bylo sedm stupňů o výšce $0,1-0,35 \mathrm{~m}$ a šířce $0,25 \mathrm{~m}$. Šířka výkopu činila $0,9 \mathrm{~m}$. Členitost stěn př́i vyústění do sklípku snad naznačuje použití jisté konstrukce při utváření vstupu, který byl široký $0,8 \mathrm{~m}$. Vlastní prostor sklípku měl přibližně kruhový půdorys o průměru $2,6 \mathrm{~m}$. Původní výška činila minimálně $2,1 \mathrm{~m}$. Nejmladší keramický materiál získaný z výplní lze datovat do období od druhé poloviny 15 . do 16 . století. V některých uloženinách však převažoval materiál z druhé poloviny 14. až první poloviny 15 . století. To byl i případ vrstvy s. j. 338, která navíc poskytla soubor pěti mincí. Jde o homogenní spektrum mincí běžně obíhajících v období husitských válek na jižní Moravě. ${ }^{3}$ Sklípek byl stratigraficky mladší než objekt s. s. j. 042, jehož výplně obsahovaly keramické zlomky ze 14. století, a jáma s. s. j. 076 s keramikou z druhé poloviny 15. století.

\section{S. s.j. 006}

Zahloubená část stavby, zřejmě suterén (obr. 10). Byla utvořena pravidelným výkopem čtvercového nebo obdélného půdorysu (s. j. 546). Stěny výkopu byly př́ímé, svislé nebo strmě šikmé, dno ploché. Př́itomné sloupové jamky (s. j. 598-601) dokládají svislé prvky dřevěných konstrukcí. Na dně se utvořila komunikační (nášlapová) vrstvička (s. j. 259). Výplň představovala s. j. 257, která by mohla být původně hliněnou složkou konstrukce stavby. Vnitřní světlost

3 Stříbrný čtyřhranný peníz markraběte Jošta (1375-1411) ražený v letech 1404-1411 v Brně; stř́ibrný čtyřhranný haléř Albrechta V. (14231435) ražený v letech 1423-1435 v Brně; stř́ibrný čtyřhranný peníz ražený městem Brnem v letech 1423-1435; stř́ibrný jednostranný fenik Albrechta IV. (1395-1404), Albrechta V. a Viléma († 1406) ražený v letech 1395-1406 ve Vídni; stříbrný čtyřhranný peníz ražený asi Albrechtem V. (1423-1435) v Brně. 
výkopu činila 4,9 ×>3,5 m. Hluboký byl minimálně $0,8 \mathrm{~m}$. Získaný keramický materiál lze datovat do období od druhé poloviny 13. do 14. století. Suterén byl stratigraficky starší než suterén s. s. j. 004.

S. s. j. 042

Situace, kterou lze označit za sklípek, popř́ípadě skladovací či zásobní jámu (obr. 11). Byla utvořena výkopem s. j. 539. Měl mírně podhloubené stěny a ploché dno, do kterého byla

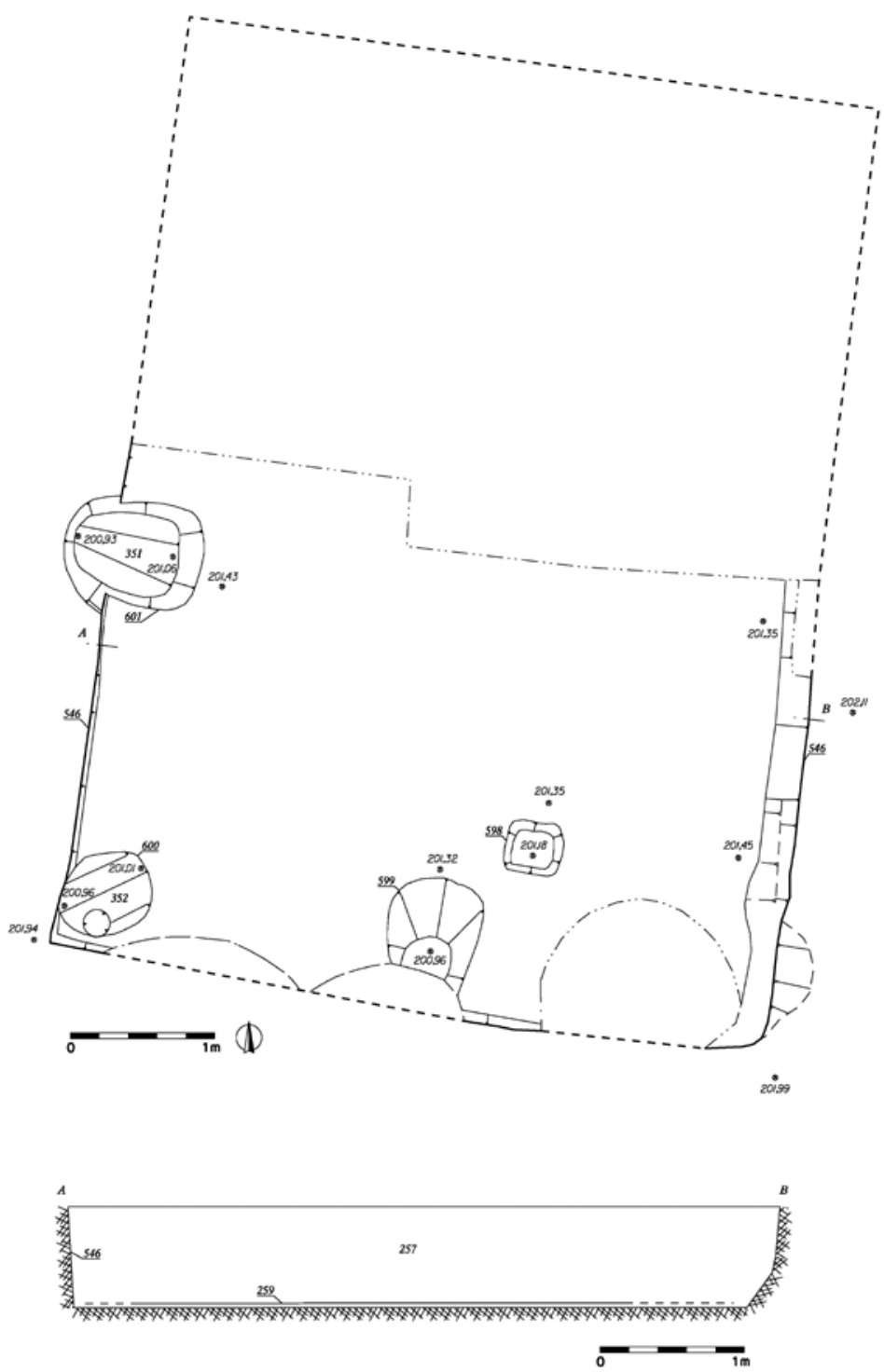

Obr. 10. Objekt s. s. j. 006 - půdorys a profil. 598-601 - výkopy sloupových jamek; 259 - nášlapová vrstvička; 257 - zřejmě hliněná složka destruované konstrukce stavby.

Abb. 10. Objekt Verband stratigraphischer Einheiten 006 - Grundriss und Profil. 598-601- ausgehobene Pfeilergruben; 259 - Gehschicht; 257 - offenbar Lehmkomponente der zerstörten Baukonstruktion. 

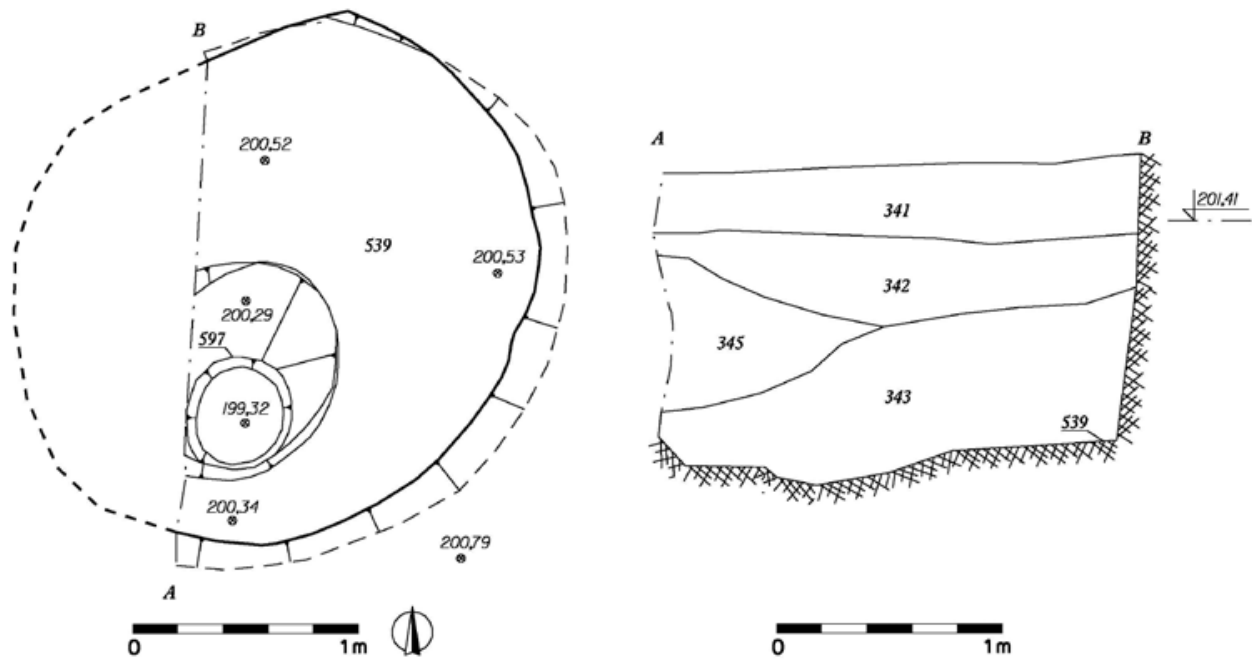

Obr. 11. Objekt s. s. j. 042 - půdorys a profil.

Abb. 11. Objekt Verband stratigraphischer Einheiten 042 - Grundriss und Profil.

zahloubena sloupová jamka s. j. 597. Do ní usazený prvek mohl souviset se zpřístupněním nebo podpíral konstrukci stropu či zastřešení. Výkop byl vyplněn uloženinami zásypového charakteru. Půdorys výkopu byl přibližně kruhový o průměru 2,5 m. Hluboký byl minimálně $1,9 \mathrm{~m}$. Převaha keramického materiálu získaného z výplní náleží do 14 . století. V případě mladších zlomků by mohlo jít spíše o kontaminaci, způsobenou zřejmě nedůsledným oddělením materiálu při styku s výplněmi stratigraficky mladšího sklípku s. s. j. 005.

\section{S. s. j. 047}

Objekt, jehož funkce nebyla přesně určena (obr. 12 a 13). Mohlo by jít o exploatační jámu, ale není vyloučena možnost, že šlo o objekt související se zástavbou. Ke spojitosti s ní vybízí především poloha v poměrně blízké vzdálenosti od čela parcely $(10,5 \mathrm{~m})$, navíc v návaznosti na zaniklé suterény staveb. Proti určení jámy jako reliktu sklepa hovoří do jisté míry její charakter. Půdorys výkopu (s. j. 552) byl v horní části přibližně oválný o rozměrech $5 \times \mathrm{ca} 4 \mathrm{~m}, \mathrm{v}$ dolní byl členitější, v hlavní partii snad kruhový o průměru $2,9 \mathrm{~m}$. Východní stěna byla stupňovitá, šikmá a rozevírala by sklep v horní hraně do prostoru. Na dně nebyla zaznamenána výraznější komunikační úroveň. Nemusela však být patrná v štěrkovopísčité vrstvě podloží, jejíhož povrchu výkop dosáhl. Některé z rysů objektu by jeho využití jako sklepa mohly nasvědčovat. Je to především hloubka, která činila minimálně $2,3 \mathrm{~m}$. V jihozápadní části bylo dno zvýšeno o $0,5 \mathrm{~m}$. Tento stupeň mohl mít ve funkčním využití sklepa svůj význam, nebo mohl souviset s jeho zpřístupněním. Je možné uvažovat také o tom, že jáma představuje destrukci raženého sklepa. Této interpretaci ovšem neodpovídá skladba výplní. Přímo na dně ležela místy vrstva, kterou lze považovat za hliněnou část nějaké konstrukce (s. j. 330, 331). Drtivou část objemu jámy vyplňovala zásypová uloženina, zřejmě odpadního charakteru (s. j. 314-316, 324, 328, 329). Museli bychom předpokládat, že by po destrukci sklepa byla odstraněna vrstva tvořící původně strop. Důvodem mohlo být její využití jako stavebního materiálu nebo byla odebrána za účelem získání příslušných věcí, pokud strop spadl ještě v době funkce sklepa. V potaz je nutné brát možnost, že v případě dokumentované jámy může jít o druhotné využití a úpravu někdejšího sklepa (at' už raženého či kopaného), která „setřela“ prvky, které by jasně potvrzovaly takovou interpretaci. 


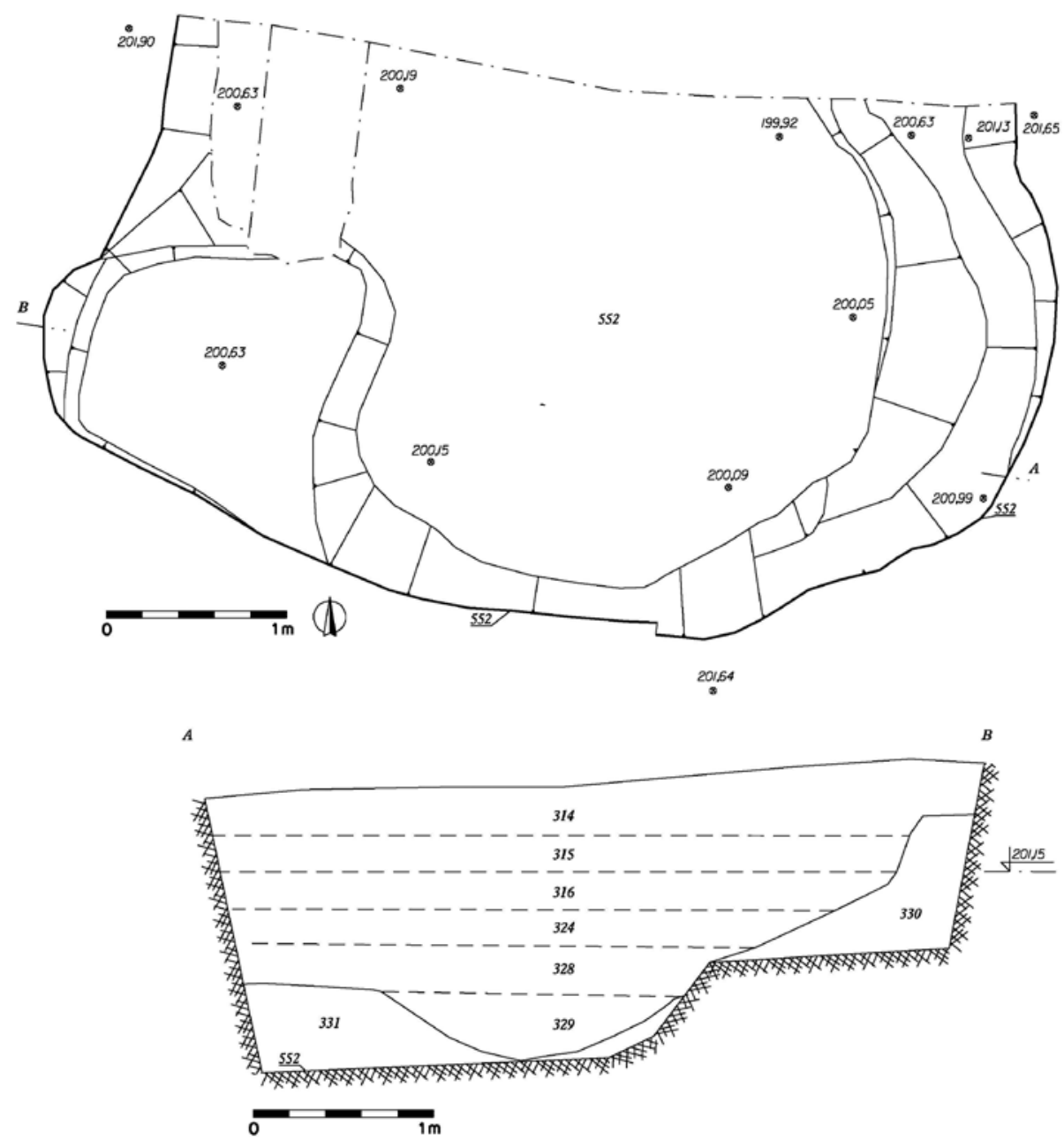

Obr. 12. Objekt s. s. j. 047 - půdorys a profil. 314-316, 324, 328, 329 - vrstvy odpadního charakteru; 330, 331 - zřejmě hliněná složka destruované konstrukce stavby.

Abb. 12. Objekt Verband stratigraphischer Einheiten 047 - Grundriss und Profil. 314-316, 324, 328, 329 - Schichten mit Abfallcharakter; 330, 331 - offenbar Lehmkomponente der zerstörten Baukonstruktion.

Keramický materiál získaný z výplní náleží do druhé poloviny 14. až první poloviny 15 . století. Vrstva s. j. 328 obsahovala minci, která určuje terminus post quem. Jde o stř́ibrný parvus ražený v Kutné Hoře. Vzhledem k nízké kvalitě ražby a špatnému stavu dochování jej nelze blíže určit. Snad náleží Janu Lucemburskému (1310-1346). Existuje i jistá pravděpodobnost, že by patřil až Karlu IV. (1346-1378). Situace byla stratigrafiky mladší než suterén s. s. j. 003.

S. s.j. 049

Snad sklípek. Byl zachycen pouze segment výkopu (s. j. 554) a část výplně. Hloubka činila minimálně $2,4 \mathrm{~m}$. Př́stup lze předpokládat $\mathrm{z}$ východní strany, kde bylo dno převýšeno o $0,6 \mathrm{~m}$. 


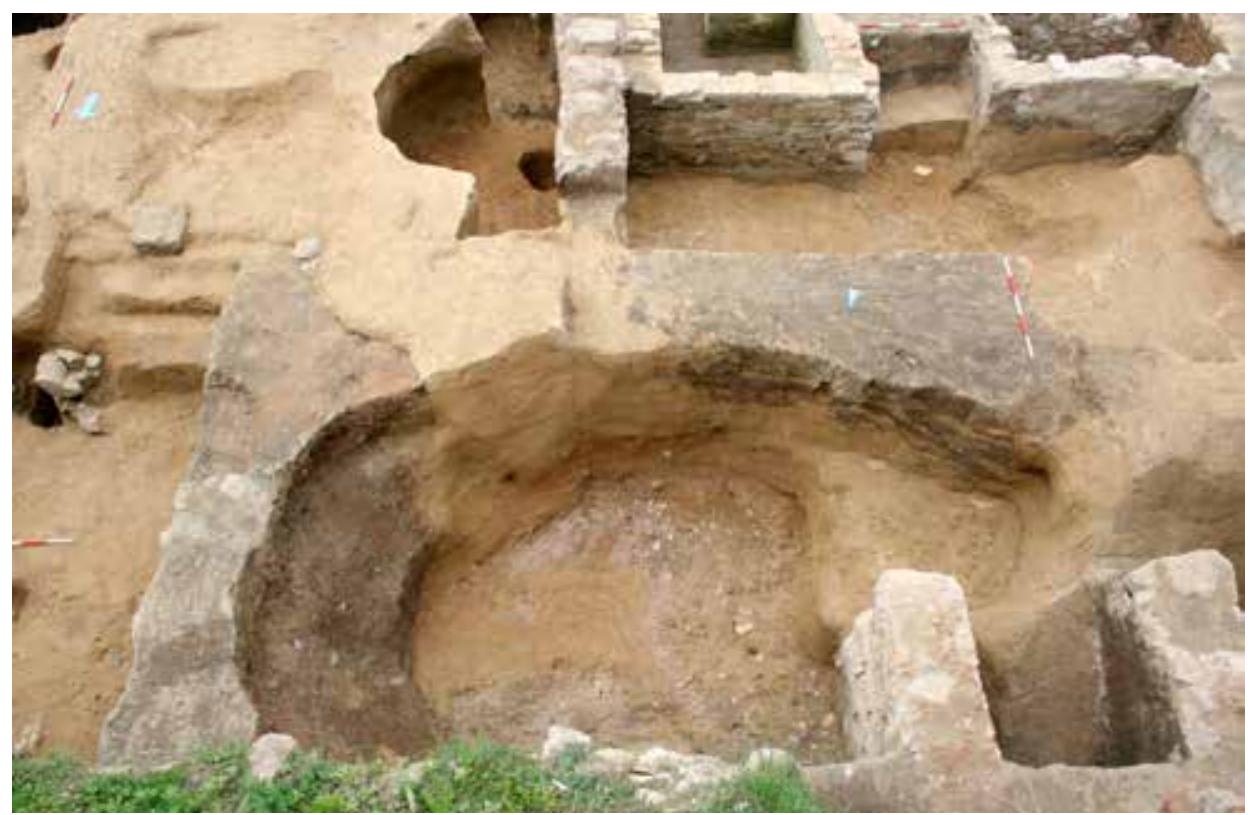

Obr. 13. Pohled od severu na objekt s. s. j. 047. Zdroj fotoarchiv Archaia Brno, o. p.s. - foto č. 8939-2013.

Abb. 13. Blick aus Norden auf das Objekt Verband stratigraphischer Einheiten 047. Quelle Fotoarchiv Archaia Brno, o.p.s. - Foto Nr. 8939-2013.

Není vyloučeno, že situace představuje pouze vstupní část do objektu s. s. j. 050. Keramický materiál získaný z výplně náleží období 14.-15. století.

\section{S. s.j. 050}

Pravděpodobně zahloubená část zástavby. Je otázkou, zda jde o suterén či do podloží ražený sklep. Byl zachycen pouze nepatrný segment výkopu (s. j. 627) a část výplní. Pro určení situace jako raženého sklepa hovoří výrazné zahloubení, které činilo minimálně $3,3 \mathrm{~m}$. Na dně výkopu se nacházela vrstvička (s. j. 1176), která mohla vzniknout komunikačním provozem. Na ní ležela vrstva s. j. 1175, kterou je možné považovat za spadený strop raženého sklípku či za hliněnou složku konstrukce stavby př́íslušející k suterénu. Následoval zásyp s. j. 1174. Není vyloučeno, že objekt s. s. j. 049 by mohl představovat vstupní část do prostoru suterénu či raženého sklepa. Ze zásypu byl získán nepočetný keramický materiál, který lze datovat nejdříve do druhé poloviny 15 . století.

\section{S. s. j. 051}

Sklípek (obr. 14 a 15). Byl zachycen pouze malý segment výkopu (s. j. 555). Půdorys lze odhadovat jako obdélný nebo čtvercový o rozměrech ca $2 \times>0,5 \mathrm{~m}$. Pokud by mělo jít o do podloží ražený objekt, musela by být vysvětlena absence vrstvy, která by tvořila původní strop. Na dně ležela komunikační (nášlapová) vrstvička s. j. 317. Následovala zásypová uloženina s. j. 223. Vstupní schodiště předstupovalo prostor sklepa. Bylo umístěno při severovýchodním rohu a směřovalo na sever. Bylo utvořeno výkopem s. j. 640, který měl př́ímé, svislé stěny a stupňovitě tvarované dno. Zachovány byly čtyři stupně o výšce $0,2-0,35 \mathrm{~m}$ a šířce $0,2-0,3 \mathrm{~m}$. Šířka výkopu činila $1 \mathrm{~m}$. Keramický materiál získaný z výplní lze datovat do období 14. až 15. století. 

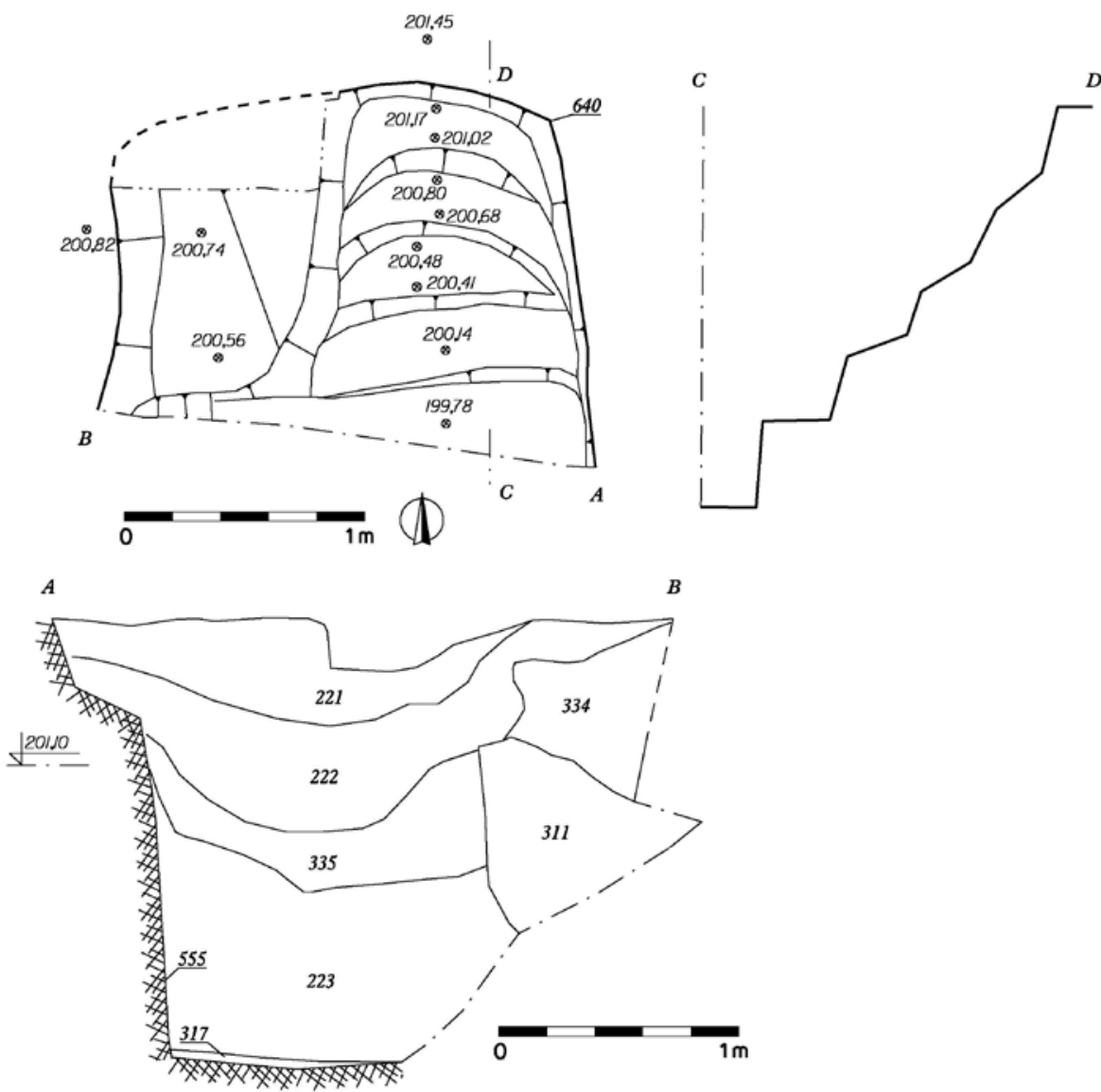

Obr. 14. Objekt s. s. j. 051 - půdorys a profil. 317 - nášlapová vrstva; 223 - zásypová vrstva.

Abb. 14. Objekt Verband stratigraphischer Einheiten 051 - Grundriss und Profil. 317-Gehschicht, 223 - Verfüllungsschicht.

S. s. j. 057

Sklípek (obr. 16). Vznikl ražbou do podložních vrstev (výkop s. j. 606). Měl přibližně kruhový půdorys o průměru $3 \mathrm{~m}$. Světlá výška činila minimálně $1,7 \mathrm{~m}$. V severovýchodní části se na něj napojovala chodba (výkop s. j. 612), která sklípek zpř́ístupňovala. Byla široká $1,1 \mathrm{~m}$. Je otázkou, zda vedla přímo ke vstupu na povrch, nebo ústila do další prostory. V mladším období zde byl vybudován zděný sklep s. s. j. 062. Není vyloučeno, že mohl mít předchůdce, který byl s raženým sklípkem propojen. Na podlaze sklepa i chodby vznikly komunikační (nášlapové) vrstvičky s. j. 284 a 294. Na nich uložená vrstva s. j. 283 představovala spadený strop. Destrukce sklípku byla následně zasypána (s. j. 291, 292, 293). Několik keramických zlomků získaných z nášlapové vrstvičky lze datovat nejdříve do druhé poloviny 15. století. Nálezový soubor ze zásypů destrukce sklepa pochází z druhé poloviny 15 . až první poloviny 16 . století.

S. s. j. 059

Sklípek (obr. 17 a 18). Vznikl zřejmě ražbou do podložních vrstev. Byl zachycen pouze segment jeho destruované jižní části (výkop s. j. 608). Měl vnitřní světlost 2,2 ×>1,5 m. Jižní stěna 


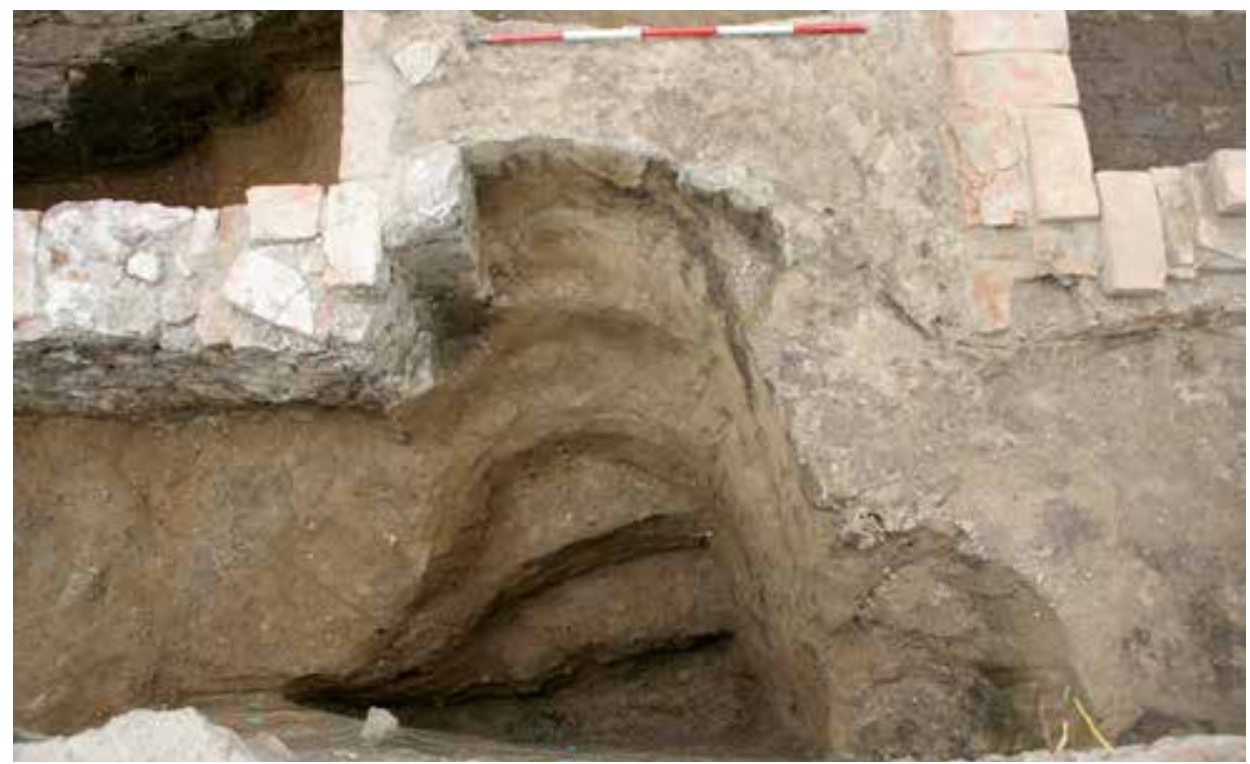

Obr. 15. Pohled od jihu na vstupní část do objektu s. s. j. 051. Zdroj fotoarchiv Archaia Brno, o.p. s. - foto č. 9036-2013. Abb. 15. Blick aus Süden auf den Eingangsteil in Objekt Verband stratigraphischer Einheiten 051. Quelle Fotoarchiv Archaia Brno, o.p.s. - Foto Nr. 9036-2013.

byla posílena zdí z kamenů pojených hlínou (s. j. 947), protože při výkopu sklípku se zde narazilo na méně soudržné výplně zásobní jámy s. s. j. 058. Dno bylo ve střední části sníženo o $0,3 \mathrm{~m}$. Sklípek musel být přístupný ze severní strany. Ze zánikových výplní byl získán keramický materiál ze 16. století. Zásypy stratigraficky starší zásobní jámy s. s. j. 058 poskytly soubor zlomků kuchyňské keramiky z období od druhé poloviny 15 . do první poloviny 16 . století. Obsahovaly také minci, která určuje terminus post quem. Jde o stř́ibrný haléř Ludvíka I. Jagellonského (1516-1526), ražený v Kutné Hoře.

\section{S. s. j. 064}

Vstupní část (schodiště) zřejmě do sklípku nebo zahloubené části stavby. Byl zachycen jen velice nepatrný segment (výkop s. j. 615). Výplň (s. j. 297) neposkytla datační materiál. Schodiště bylo pravděpodobně stratigraficky starší než ražený sklípek s. s. j. 057. Na místě objektu, kterému sloužilo, byl v novověku vybudován zděný sklep s. s. j. 062.

\section{S. s.j. 077}

Sklípek (obr. 19). Vznikl zřejmě ražbou do podložních vrstev (výkop s. j. 634). Měl přibližně oválný půdorys o rozměrech $3,8 \times$ ca $2,8 \mathrm{~m}$. Světlá výška činila minimálně $1,6 \mathrm{~m}$. Blok podloží, který umožňoval př́stup do sklípku, byl ponechán v interiéru $(2,5 \times 1,2 \mathrm{~m})$. Mohla o něj být opřena dřevěná konstrukce. Keramický materiál odebraný ze zánikových výplní pochází z období 14.-15. století.

\section{Suterény}

Situace s. s. j. 003, 004 a 006 jsou typickými představiteli kategorie objektů, které označujeme jako suterény dřevohliněných staveb. Potkáváme se s nimi při archeologických výzkumech 

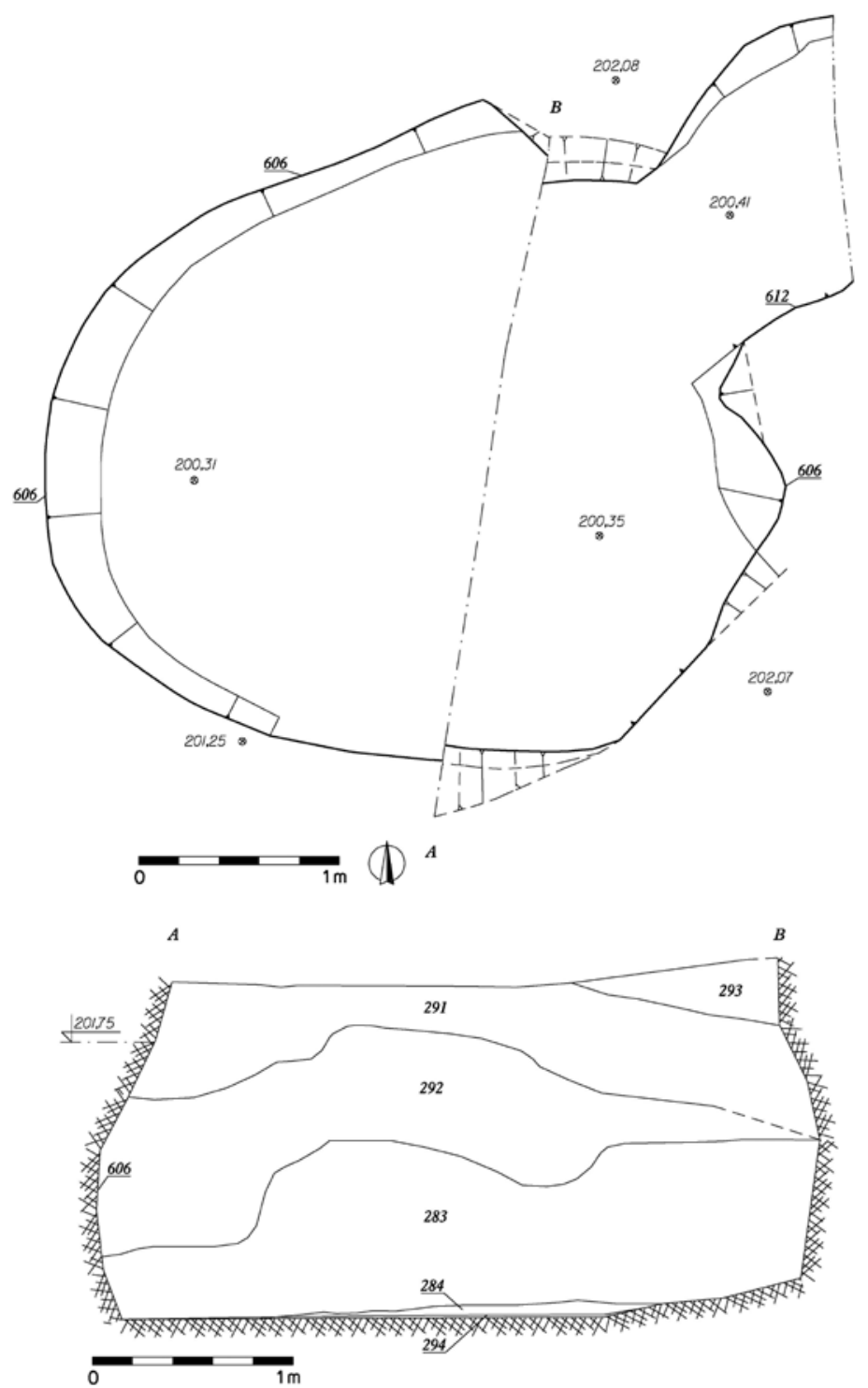

Obr. 16. Objekt s. s. j. 057 - půdorys a profil. 283 - spadený strop sklípku; 284, 294 - nášlapové vrstvičky; 291-293 - zásypové vrstvy.

Abb. 16. Objekt Verband stratigraphischer Einheiten 057 - Grundriss und Profil. 283 - eingestürzte Kellerdecke; 284, 294 Gehschichten; 291-293 - Verfüllungsschichten.

takřka na všech někdejších městištích ve vnitřním městě (souhrnně včetně katalogu naposledy Holub a kol. 2005) a jsou registrovány také při výzkumech historických předměstí, která tvořila průběžný pás osídlení kolem městských hradeb (Černá a kol. 2012, 107; Černá a kol. 2014, 182; Holub a kol. 2006, 184, 202; Holub a kol. 2008, 363). Několik případů bylo zaznamenáno rovněž při archeologických akcích v Králově Poli (Holub a kol. 2006, 205; Holub a kol. 2007, 438, 439). 

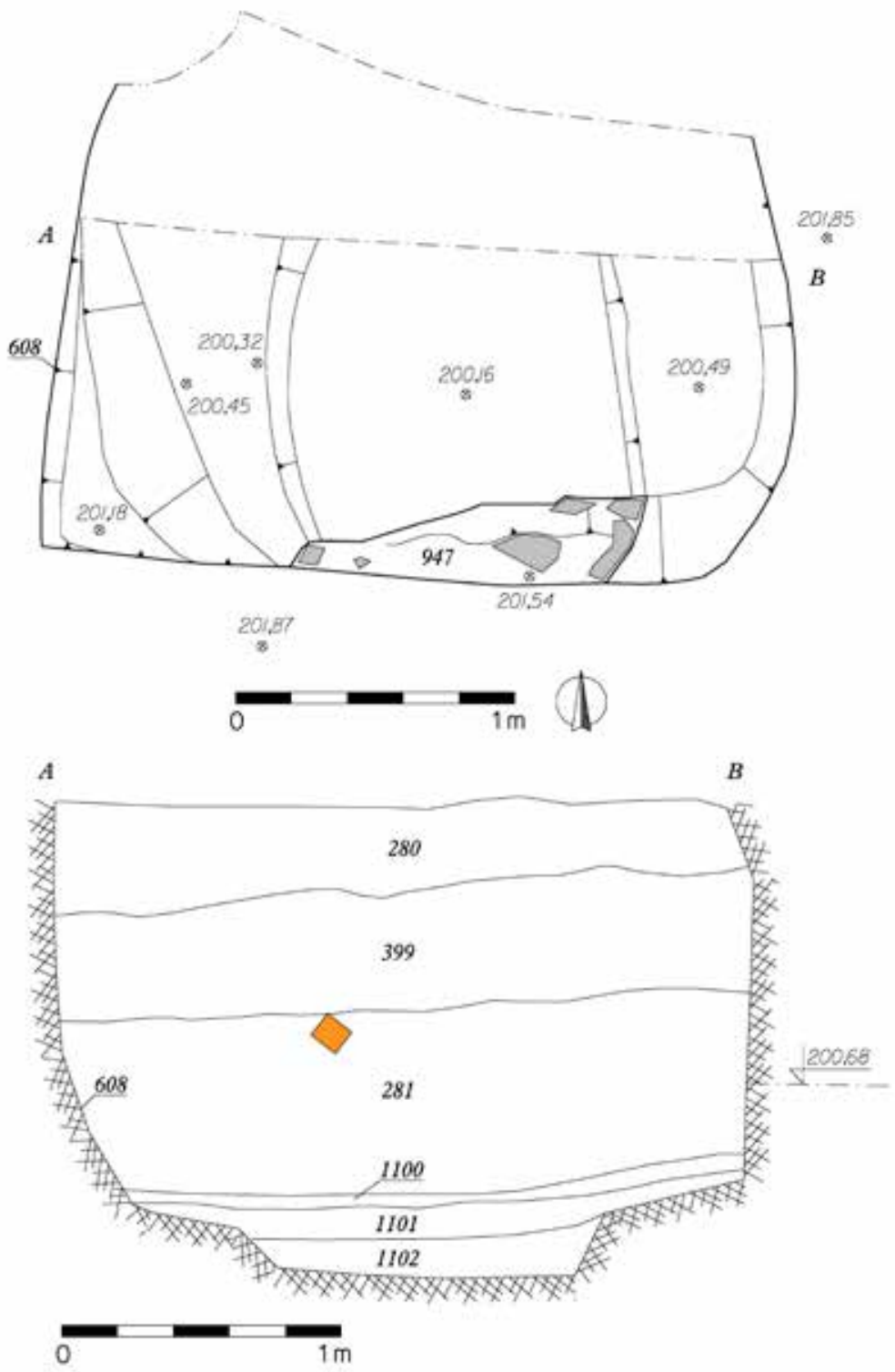

Obr. 17. Objekt s. s. j. 059 - půdorys a profil. 947 - vyzdění stěny.

Abb. 17. Objekt Verband stratigraphischer Einheiten 059 - Grundriss und Profil. 947 - Wandausmauerung.

Jde o zahloubené prostory většinou obdélných či čtvercových půdorysů, které sloužily jako sklepy domů či hospodářských budov. Př́istupné byly předsazeným vstupním schodištěm či vstupní šíjí. Stěny sklepů byly zpevněny dřevěnými konstrukcemi. Jejich umístění na parcelách bývá rozmanité. $\mathrm{V}$ dvorních částech zřejmě přináležely spíše $\mathrm{k}$ hospodářským budovám. $\mathrm{V}$ případě menších staveb (např. typu špýcharů) mohl být podsklepen celý prostor. U suterénů, které jsou vázány na přední část parcely, lze předpokládat, že náležely $\mathrm{k}$ př́islušným domům, jež stály $\mathrm{v}$ jejich čele. Rozsah těchto suterénů je rozličný. V Brně byly dosud dokumentovány případy 


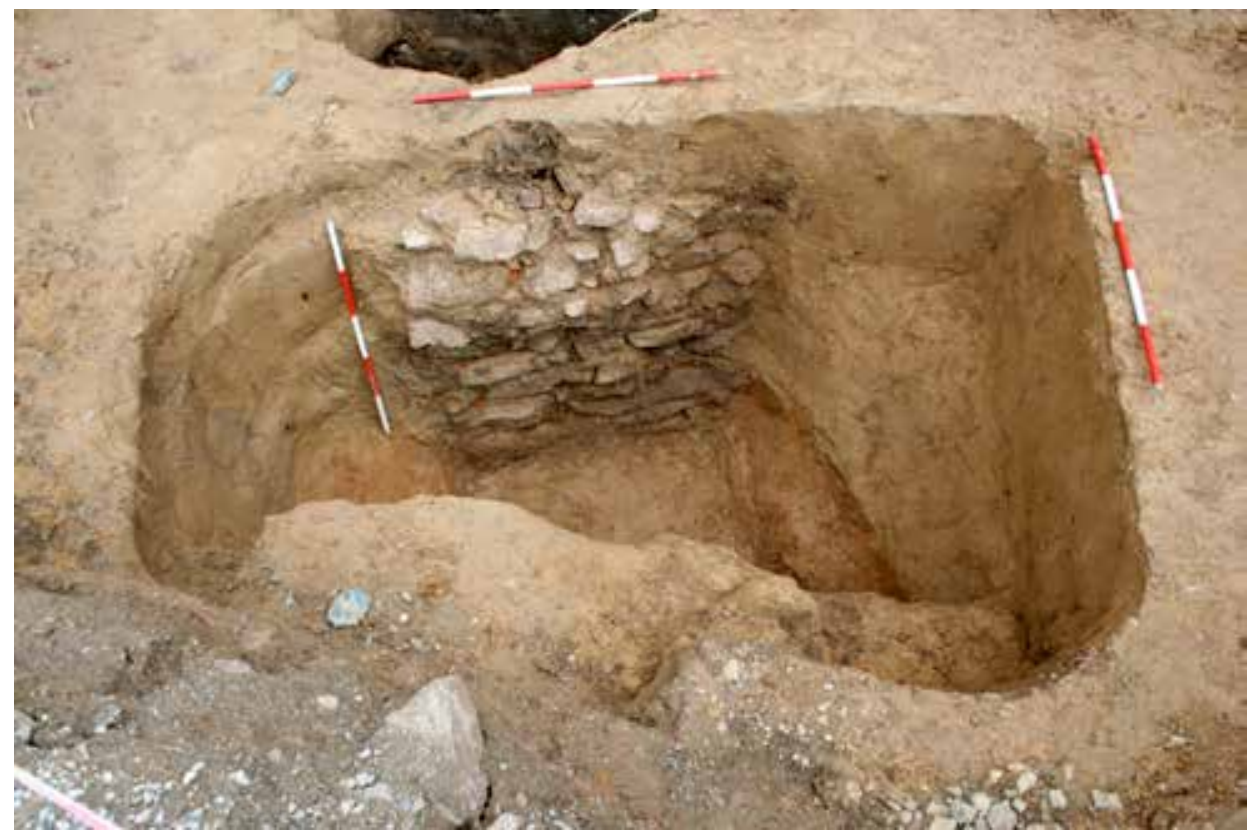

Obr. 18. Pohled od severu na objekt s. s. j. 059. Je patrné vyzdění jižní stěny. Zdroj fotoarchiv Archaia Brno, o.p.s. - foto č. 9058-2013.

Abb. 18. Blick aus Norden auf Objekt Verband stratigraphischer Einheiten 059. Erkennbar ist die Ausmauerung der Südwand. Quelle Fotoarchiv Archaia Brno, o.p.s. - Foto Nr. 9058-2013.

v rozmezí 16 až $157,5 \mathrm{~m}^{2}$. Některé z nich byly členěny prostřednictvím příček na dílčí prostory. V případě suterénů menších a středních velikostí předpokládáme, že jimi byla podsklepena pouze část př́islušného domu. U některých rozsáhlejších objektů je možné, že zabíraly téměř celý půdorys domu (napřs. suterén s. s. j. 002 z náměstí Svobody 17 o výměře $120 \mathrm{~m}^{2}-$ Holub a kol. 2005, 89-90). Do první skupiny náležejí suterény v čele parcely Vídeňská 6. Vstup známe pouze u jednoho z nich. Je možné, že směřoval do průjezdu štítově orientovaného domu, který byl suterénem částečně podsklepen. Stěny všech suterénů na Vídeňské ulici byly zajištěny dřevěnou konstrukcí. Její svislé prvky tvořily do podlahy zapuštěné dřevěné sloupy. Horizontální části konstrukce mohly představovat štípané prvky, desky nebo drobnější kulatina. V případě suterénu s. s. j. 003, kdy se na základě dokumentované situace zdá, že sloupy těsně doléhaly na stěnu výkopu, je možné uvažovat o tom, že vodorovné stavební prvky nebyly upevňovány za sloupy, ale např́ḱlad do drážek v nich utvořených. Konstrukce se sloupy zapuštěnými do podlahy byly užity také u suterénů v Králově Poli. Známe je rovněž z prostoru města. Zde jsou ale dokumentovány také objekty, u nichž byla užita odlišná technika. V archeologickém terénu se po ní většinou zachovává jako dominantní prvek žlábek po trámu uloženém podél stěny. Do něho byly usazovány svislé prvky. Uvažovat lze o tzv. rámové konstrukci. Suterény jsou ve městě typickým prvkem pro období 13.-14. století. Stejně jsou datovány objekty z Králova Pole a suterény z Vídeňské ulice. Popsané objekty z parcely domu č. 6. jsou jedinými zástupci této kategorie, které byly dosud na Vídeňské ulici zkoumány. Nejbližší další suterén (ca 100 východně od průčelí kostela sv. Leopolda na Vídeňské ulici) byl dokumentován výzkumem realizovaným při výstavbě nového pavilonu Nemocnice Milosrdných bratří (akce č. A70/2002). Přináležel zřejmě zástavbě uskupené podél Polní ulice. Byl utvořen obdélným výkopem o rozměrech $6,1 \times 4,7 \mathrm{~m}$, hloubka přesahovala $1,5 \mathrm{~m}$ a byl vybaven vstupní šijí. Konstrukce stěn nebyla přesně určena. 

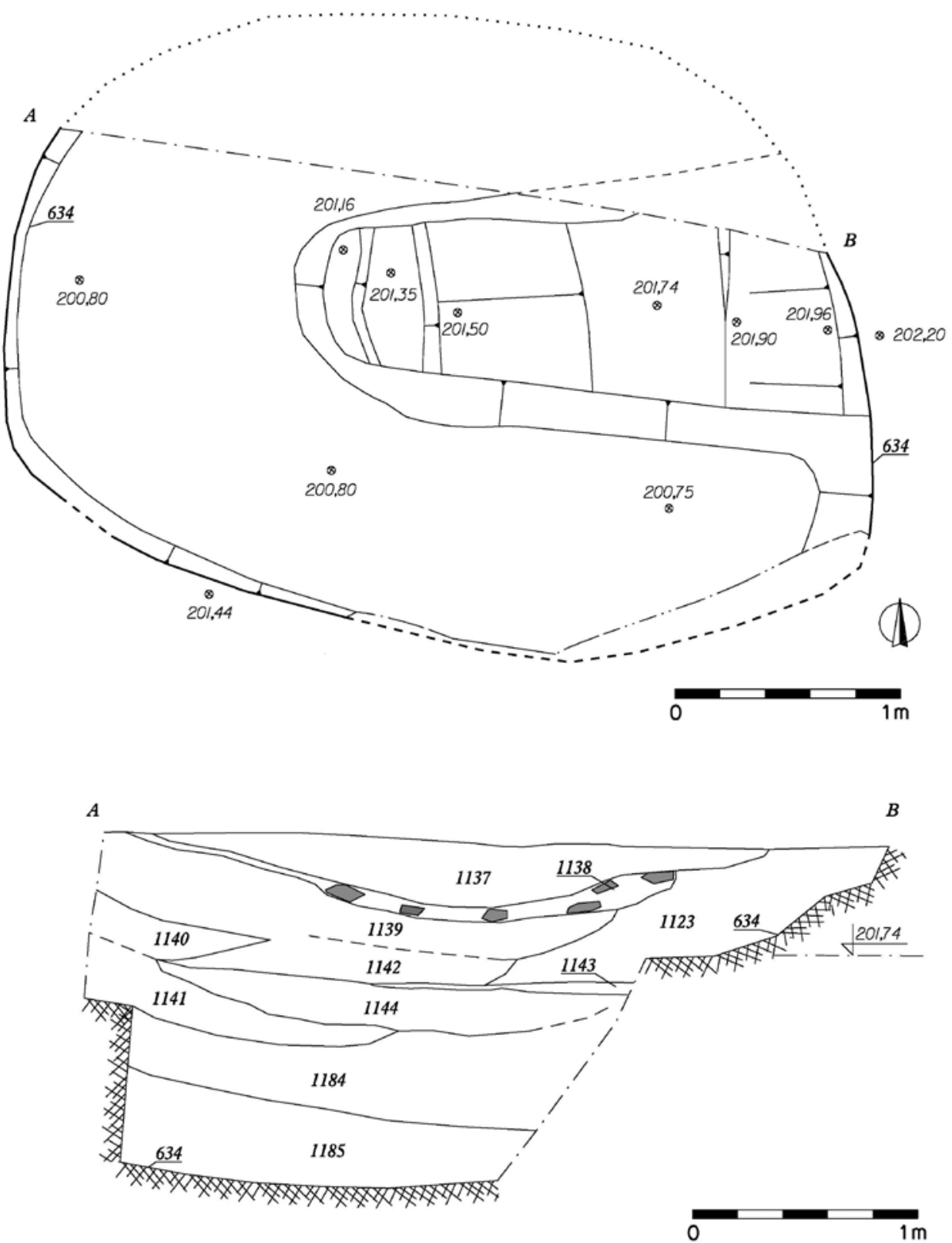

Obr. 19. Objekt s. s. j. 077 - půdorys a profil.

Abb. 19. Objekt Verband stratigraphischer Einheiten 077 - Grundriss und Profil. 
Zánik suterénu byl zasazen do období od konce 13. do první poloviny 14. století (ZapletalováHložek 2010, 137-140).

\section{Sklípky / zásobní jámy}

Interpretace objektu s. s. j. 042 jako sklípku není zcela jednoznačná. Zda náležel k nějaké budově, se nepodařilo prokázat. Zastřešení alespoň formou „lehčí konstrukce by ovšem pro fungování objektu jako skladovacího prostoru bylo nezbytné. Objekty s obdobným tvarem z prostoru města neznáme. Typově a možnostmi svého využití však objekt s. s. j. 042 odpovídá skupině útvarů, které byly interpretovány jako kopané sklípky. Jde o nevelké výkopy čtvercového nebo obdélného půdorysu s plochým dnem, na němž byla př́ítomna nášlapová vrstvička. Jednoznačně identifikovány byly doposud dva zástupci, jeden na Dominikánské 5 (parc. č. 474, s. j. 2504 - akce č. A00/10), druhý na náměstí Svobody 17 (parc. č. 524, s. j. 550 - akce č. A191/2000). První měl rozměry 2,3 × 1,5 m, druhý $2,4 \times 2,3 \mathrm{~m}$ a v jednom z jeho rohů byla zahloubena sloupová jamka. Dokumentované hloubky činily 2,5 a 2,2 m. Návaznost objektů k nadzemním konstrukcím nebyla zachována. Od uliční čáry byl sklípek z náměstí Svobody 17 vzdálen $21,5 \mathrm{~m}$, objekt z Dominikánské ulice $12 \mathrm{~m}$, tedy stejně daleko jako v př́ípadě objektu s. s. j. 042. Ve vývoji zástavby parcel náleží popsané sklípky do nejstarší fáze. Datovat je můžeme do první třetiny 13. století (Holub a kol. 2005, 46, 66). Zřejmě dalším zástupcem této kategorie byl objekt s. s. j. 003 z Jakubského náměstí (parc. č. 44, akce č. A32/2011). Měl rozměry $2,2 \times 2 \mathrm{~m}$ a dokumentovanou hloubku $2,5 \mathrm{~m}$. Na plochém dně byla opět př́itomna nášlapová vrstvička. Terénní situace umožňovala interpretaci, že sklípek byl součástí stavby, jejíž nosnou část konstrukce tvořily zapuštěné dřevěné sloupy. Po začlenění př́slušného městiště do areálu svatojakubského hřbitova byl prostor sklípku využit k pohřbívání. Nelze ovšem zcela vyloučit možnost, že o sklípek nešlo a výkop byl utvořen až v souvislosti s pohřbíváním. Situaci je možné datovat nejpozději do 14. století (Zůbek 2016, 88, 91). Popsané sklípky mají přibližně stejné parametry. Objemovou kapacitou jim odpovídá objekt s. s. j. 042. Obdobným způsobem musel být řešen také př́istup (např́iklad žebřík či ostrev). Signifikantní je poměrně výraznější zahloubení, které by mohlo ukazovat na snahu dosáhnout v úrovni dna stabilnějších tepelných podmínek. Objekty je možné spojovat s uchováváním př́íslušných potravin. Jejich výskyt na dalších lokalitách by mohlo potvrdit tímto směrem zaměřené revizní zpracování př́slušných archeologických výzkumů.

\section{Ražené sklípky}

Jde o objekty utvořené podpovrchovým hloubením. Tímto způsobem vznikla vlastní prostora sklípku. Tyto sklípky jsou vybaveny vstupem ústícím na povrch terénu. Typickým představitelem této skupiny je sklípek s. s. j. 005. Zařazeny sem mohou být objekty s. s. j. 049, 050, 051, 057 a 059. Je však nutné si uvědomovat možnou problematičnost tohoto začlenění, která je způsobena nedostatečně zachovalou terénní situací. Týká se to především objektů s. s. j. 049 a 050, jejichž parametry zůstaly $\mathrm{v}$ podstatě neznámé. $V$ případě s. $s$. j. 051 známe vstupní část, není ovšem zcela jisté, zda náležela raženému nebo z povrchu hloubenému sklepu. Naopak u sklípků s. s. j. 057 a 059 byla zachycena jejich prostora, zpřístupnění ale zůstalo neznámé. V těchto případech nelze vyloučit možnost, že nejde o ,jednoduché“ sklípky se vstupem, ale o součást složitějších útvarů, které jsou označovány jako lochy. Stávající literatura je definuje většinou jako složitější chodbovité útvary, často se jedná o několik chodbami propojených sklípků (souhrnně k lochům na Moravě naposledy Kos 2002; 2005). Do kategorie ražených sklípků se vstupem náleží objekt s. s. j. 007. Jde o variantu, kdy těleso vstupu zasahuje z velké části do vlastní prostory sklepa. V brněnských podmínkách nebyl dosud obdobný případ zaznamenán.

Naproti tomu sklípky se vstupem, který vychází z jejich půdorysu, nejsou ojedinělou záležitostí. Několik typických př́kladů bylo zaznamenáno při výzkumech v Králově Poli (Božetěchova 1-3 - akce č. A101/2004 - objekty s. s. j. 001, 041, 037, 101 - Holub-Sedláčková 
2005; Mojmírovo náměstí 15a - akce č. A104/2004 - objekt s. s. j. 001 - Holub a kol. 2007, 438, 439; Polánka-Sedláčková-Zůbek 2006a), nejméně jeden sklípek známe z výzkumu na Kopečné ulici. Náležel $\mathrm{k}$ výbavě parcely předměstské osady $\mathrm{v}$ bezprostředním sousedství města (akce č. A37/2013 - s. s. j. 004 - Černá-Zůbek 2015; Zůbek 2016b, 353). V prostoru vlastního města nebyl dosud dokumentován žádný př́ipad, který by mohl být do této kategorie jednoznačně zařazen. Může to být ovšem pouze stav výzkumu. Dokumentována byla řada objektů ražených pod povrchem terénu. Jejich souhrnné zpracování nebylo dosud provedeno a jistě by mělo žádaný prŕnos. Torzovité zachování terénní situace či technické podmínky výzkumu zatím většinou neumožnily jednoznačnou interpretaci. Velká část objektů bude zřejmě souviset spíše s kategorií lochů. Bylo registrováno několik sklípků vázaných na zahloubené suterény dřevohliněných staveb (jednoznačně objekt č. 607 z Rašínovy 6 - akce č. A30/97, pravděpodobně objekt č. 615 a 582/614 ze Starobrněnské 2-4 a 6 - akce č. UB49/97 - Holub a kol. 2005, 45, 46, 94). Jednoznačné doklady ražených sklípků se vstupem postrádáme také z brněnských předměstí. Situace zde však může opět odrážet stav výzkumu. Důležité informace určitě přinese zpracování výsledků výzkumu, který se realizoval na poměrně velké ploše třetí předměstské čtvrti v roce 2013 (akce č. A1/2013 - Černá a kol. 2014, 180-185).

Jmenovaný případ z Kopečné ulice je výjimkou. Jedná se o specifickou lokalitu, kde příslušná parcela je zaříznuta do prudkého svahu. Tyto terénní podmínky mohly svým způsobem zjednodušovat výstavbu, a tím „vybízet“ k vytváření ražených objektů rozličného druhu. Na zkoumané ploše jich bylo zachyceno hned několik (Zůbek 2016a). Geomorfologické podmínky lokalit na Vídeňské ulici a $\mathrm{v}$ Králově Poli jsou obdobné. V obou případech se jedná o svahy s mírným sklonem. Městské parcely jsou ploché nebo vyměřené na mírném svahu. Na pozemcích kolem vršku Petrova, kde je terén místy poměrně strmý, nebyl dosud proveden adekvátní počet výzkumů. Vedle geomorfologických podmínek má na výstavbu ražených sklípků nejpodstatnější vliv skladba podloží, které musí mít dostatečnou soudržnost. V brněnských podmínkách jde většinou o spraše - hlíny, které vedle dobré statické únosnosti nabízejí i poměrně snadné podmínky pro hloubení. Stabilita byla dostatečná natolik, že nevyžadovala žádné zajišt'ující konstrukce stropu a stěn sklípků. Výzkumy nezachytily u žádného z objektů jejich stopy.

Je otázkou, zda by výstavba ražených sklípků mohla být odrazem potřeb obyvatel z rozdílných sociálních prostředí. Mohla by tak být vyložena nastíněná situace v brněnské oblasti, kdy z prostoru vlastního města ražené sklípky jako solitérní objekty neznáme, naproti tomu v okolních osadách je registrujeme téměř při každém archeologickém výzkumu realizovaném na někdejších parcelách. Ve vyhodnocení této skutečnosti ale musíme být opatrní. Může být např́íklad pouze odrazem rozdílné úrovně zachování archeologického terénu, kdy mimo vlastní historické jádro města je povětšinou zachovalost vyšší. Ovšem četnost výzkumů na městištích uvnitř hradeb je už taková, že vybízí k domněnce, že ražené sklípky se samostatným vstupem nebyly běžnou součástí jejich vybavenosti. Jednoznačnějším závěrům však musí předcházet pečlivá revize a zpracování všech dosavadních situací a rozšiření pramenné základny prostřednictvím dalších výzkumů. Ražené sklípky známe z prostoru Zelného trhu, který ve středověku představoval jedno z hlavních tržišt' města (Horní trh). Byly součástí vybavení budovy masných krámů (př́íslušný výzkum nebyl dosud zcela vyhodnocen a publikován - akce č. A15/2014 - předběžně Kolařík a kol. 2016, 260-261). Stavební technologie ražby pod terénem byla ve městě užívána při výstavbě některých novověkých zděných sklepů.

Ražené sklípky mohly ze své podstaty fungovat jako samostatné objekty, nemusely být nevyhnutelně vázány na nadzemní stavbu. Bylo jen nutné zajistit vstup proti nepřízni počasí. Takové zajištění mohla představovat účelová konstrukce. Nebo vstup mohl vycházet z nějaké stavby, přičemž vlastní sklípek mohl být zbudován mimo její půdorys (tak je tomu u několika zkoumaných sklípků masných krámů na Zelném trhu). Brněnské prrípady k řešení této problematiky nepřinášejí potřebné informace. Výzkum č. A101/2004 v Králově Poli dokumentoval, že vstup do sklípku s. s. j. 037 na Božetěchově 1-3 byl zastřešen konstrukcí využívající dřevěné sloupy. Možnost, že by byl vázán na nadzemní stavbu, ale zcela nevyloučil. Pozice sklípků na parcelách je rozmanitá. Názornou ukázku představuje zkoumaná plocha na Božetěchově 1-3. 
V případě Vídeňské ulice byly registrovány v čelní a střední části parcel, nejhlouběji usazené objekty byly od ulice vzdáleny $20 \mathrm{~m}$. Ve stejné vzdálenosti byl zaznamenán sklípek s. s. j. 004 na Kopečné ulici, šlo však již o samotnou hranici parcely tvořenou zářezem svahu. Je vysoce pravděpodobné, že sklípky v pozicích při čele parcely byly spojeny s domem. Na Vídeňské 6 by to byl prrípad sklípku s. s. j. 005. Ten se ve své funkci mohl stát nástupcem starších zahloubených suterénů. Obdobný př́ípad představuje sklípek s. s. j. 001, který se nacházel dokonce v př́mé superpozici se starším suterénem s. s. j. 013 při čele parcely Mojmírovo náměstí 15a v Králově Poli.

Pozice sklípků byla jistě úzce provázána s jejich účelem. Jako hlavní roli plnily tyto objekty zřejmě funkci skladovacích prostor. K otázce, co přesně bylo do sklípků ukládáno, nepřinesly brněnské výzkumy žádné poznatky. Velice pravděpodobně se jednalo o potraviny, především té kategorie, která vyžaduje podmínky (teplota, vlhkost), které mohly sklípky tohoto typu nabídnout. V jistém směru mohly mít díky uzavřenému „hliněnému“ prostoru lepší vlastnosti než klasické zahloubené suterény. Druh skladovaného zboží se mohl odrážet i do pozice sklípků na parcele a jejich velikosti. Plocha ražených sklípků se často pohybuje kolem hodnoty 6 až $8 \mathrm{~m}^{2}$. Tak tomu bylo i u sklípků na Vídeňské ulici. V př́ípadě objektu s. s. j. 077 však byla skladovací plocha podstatně omezena umístěním tělesa vstupu do jeho interiéru. Z Králova Pole známe také sklípky menších rozměrů. V př́ípadě objektů s. s. j. 041 a 101 z Božetěchovy 1-3 se jednalo o pouhé kaverny při úpatí schodišt' (plocha 1-2 $\mathrm{m}^{2}$, výška 0,6 a $1 \mathrm{~m}$ ). Pokud byla situace správně vyhodnocena a dokumentována, bylo by nutné je vyčlenit jako samostatnou kategorii objektů. ${ }^{4}$

\section{Vývoj zástavby}

Archeologický výzkum se odehrál na pozemku, který má šiřku $22 \mathrm{~m}$ a délku $43 \mathrm{~m}$. Sloučil dvě původní parcely, které byly delší osou orientovány kolmo ke komunikaci (dnes Vídeňské ulici). Severní parcela patřila domu Vídeňská 6 , jižní domu Vídeňská 8 , který podle archivních pramenů tvořil po jistou dobu jeden majetkový celek s dnešním domem Vídeňská 10 (viz např. indikační skica z roku 1825 - Moravský zemský archiv, sign. MOR000818250, kde je pozemek obou domů označen jedním parcelním číslem 205, později členěno na 205a, 205b).

Rekonstruovat přesný stavební vývoj parcel není na základě výsledků archeologického výzkumu možné (přehled dokumentovaných situací viz obr. 20 a 21). Informační př́ínos k tématu byl omezen nízkou mírou zachování terénních situací (pouze výrazněji zahloubené situace) a neúplností exkavace (nezkoumány zůstaly poměrně velké části plochy - viz oddíl Archeologický výzkum). Nejstarší vrcholně středověké situace lze datovat do období od druhé poloviny 13. do 14. století. Ovšem osídlení z první poloviny 13. století zcela vyloučit nelze. Využívání parcel pokračovalo zřejmě kontinuálně až do 20. století. Získané poznatky napovídají, že pozemek byl na dvě parcely rozdělen již od středověku. Hlavní část zástavby byla umístěna $\mathrm{v}$ jejich čele při uliční čáře. Jasně to prokázala situace na parcele domu Vídeňská 6. Již pro nejstarší období zde byly doloženy tři nezděné suterény ve vzájemné časově posloupné superpozici (s. s. j. 006-004006). Př́islušné domy nejspíš plnily především obytnou funkci. Samozřejmě mohly být využivány víceúčelově. Pro období 14.-15. století jsou ve stejném prostoru doloženy dvě zásobní jámy (s. s. j. 043 a 053). Snad byly vyhloubeny v hospodářské části stavby. Jsou však známy případy situování obilních jam v obytných prostorách domu (Kunz 1965, 158; 2004, 39, 77, 80). Dispozici domů nelze přesně stanovit. V případě nejmladšího suterénu s. s. j. 003 a objektu s. s. j. 047 je patrná tendence umístění zahloubených prostor dále od ulice. Lze uvažovat o domě, který byl k uliční čáře orientován štítově, nebo o okapově orientované stavbě s dvorním křídlem. Dispozice se zřejmě v průběhu doby měnila. Sklípky s. s. j. 005, 049, 050 a 051 ze 14.-16. století byly na rozdíl od předchozích objektů vybudovány př̀i jižní hranici parcely. V případě raženého sklípku s. s. j. 005 není jisté, zda součástí stavby byl jen vstup do něj, nebo byl pod stavbou umístěn celý.

4 Příslušný výzkum č. A101/2004 byl doveden pouze do podoby nálezové zprávy. Velice zajímavé doklady zahloubených částí zástavby by si zasloužily revizi a podrobné vyhodnocení. Existující monografické zpracování v podobě bakalářské práce je nedostačující (Poláčková 2006). V tomto ohledu nelze než litovat, že nebyla dokončena disertační práce vedoucího archeologického výzkumu, která měla mimo jiné shrnout výsledky této akce. 


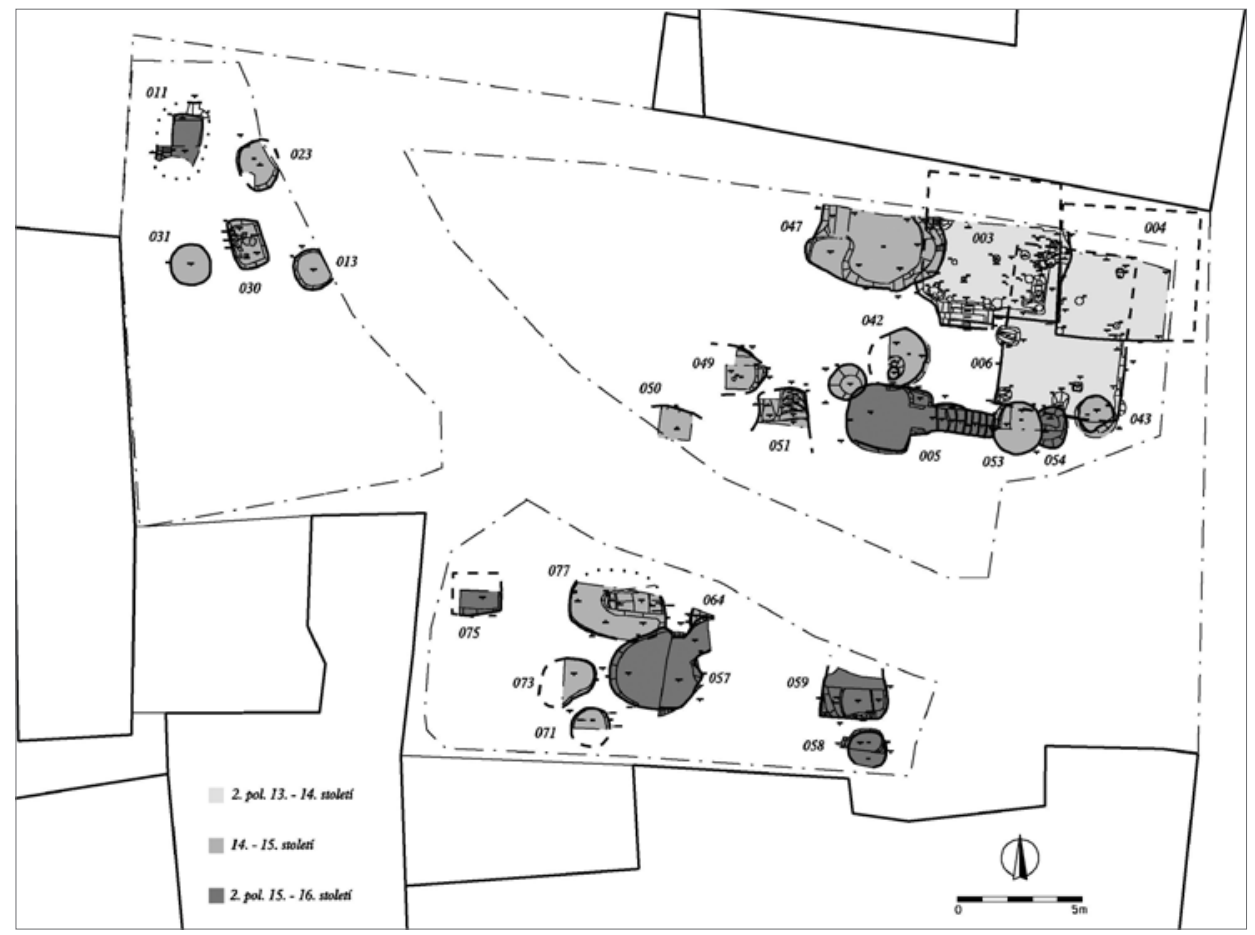

Obr. 20. Přehled zkoumaných situací ze 13.-16. století. Světle šedou barvou podbarveny aktivity z druhé poloviny 13. až 14. století, středně šedou ze 14. - 15. století, tmavě šedou z druhé poloviny 15. až 16 . století. 003, 004, 006 - suterény; 005 , 042?, 047?, 049?, 050?, 057, 059, 077 - sklípky; 051, 064 - vstupní části sklípků/suterénů; 043, 053, 058 - zásobní jámy; 071, 075 - odpadní jímky?; 011, 013, 023, 030, 031, 054, 073, 076 - jámy neznámé funkce.

Abb. 20. Übersicht der untersuchten Situationen aus dem 13. - 16. Jahrhundert. Hellgrau - Aktivitäten aus der zweiten Hälfte des 13. bis 14. Jahrhunderts, mittelgrau 14. bis 15. Jahrhundert, dunkelgrau zweite Hälfte 15. bis 16. Jahrhundert. Souterrains: 003, 004, 006 - Souterrains; 005, 042?, 047?, 049?, 050?, 057, 059, 077 - Keller; 051, 064 - Eingangsteil der Keller / Souterrains; 043, 053, 058 - Vorratsgruben; 071, 075 - Abwassergruben?; 011, 013, 023, 030, 031, 054, 073, 076 Gruben unbekannter Funktion.

Není vyloučena ani možnost, že se jednalo o solitérní objekt. Pravděpodobné je to u sklípků s. s. j. 049 až 051 , které jsou od čela parcely již poměrně více vzdáleny (16-20 m). Na parcele domu Vídeňská 8 by takovým objektem mohl být ražený sklípek s. s. j. 077, vzdálený od ulice $21 \mathrm{~m}$. Blíže k čelní hranici umístěné sklípky s. s. j. 057 a 059 mohly být součástí objektu typu lochu. Je možné, že byly spojeny s prrípadným sklepem, který by představoval suterénní část patrně zadní partie dvorního křídla či štítově orientovaného domu. V období 17.-18. století byl v tomto prostoru vybudován zděný sklep (s. s. j. 062). Zřejmě ve stejné době vznikl zděný sklep také při uliční čáře (s. s. j. 085). Naproti tomu čelo parcely Vídeňská 6 zůstalo nepodsklepeno. Zděný sklep byl dokumentován pouze ve střední části této parcely (20 m od ulice - s. s. j. 007). Je otázkou, zda zástavba př́islušná k těmto sklepům byla rovněž zděná. Pravděpodobně mohlo docházet (především v přechodném období) ke kombinaci užití stavebního materiálu a vedle sebe mohly stát budovy zděné i stavby dřevěných konstrukcí. V mladším období již postrádáme suterénní prostory a sklípky, které by nebyly vyzděny. V nejmladší fázi byla zástavba výhradně zděná. Tak je znázorněna na indikační skice z roku 1825. Na dalších plánech z 19. století lze poměrně dobře sledovat stavební vývoj zástavby. ${ }^{5}$ Je z nich jasně patrné, že několikrát změnila

5 Např. katastrální mapa z roku 1840-1841 - Archiv města Brna, fond U 9, sign. KAT 154; mapa Th. Schönaicha z roku 1868 - Archiv města Brna, fond U 9, sign. K 37a; plán z roku 1895 - Archiv města Brna, fond A 1/33, inv. č. 714, kart. 138. 


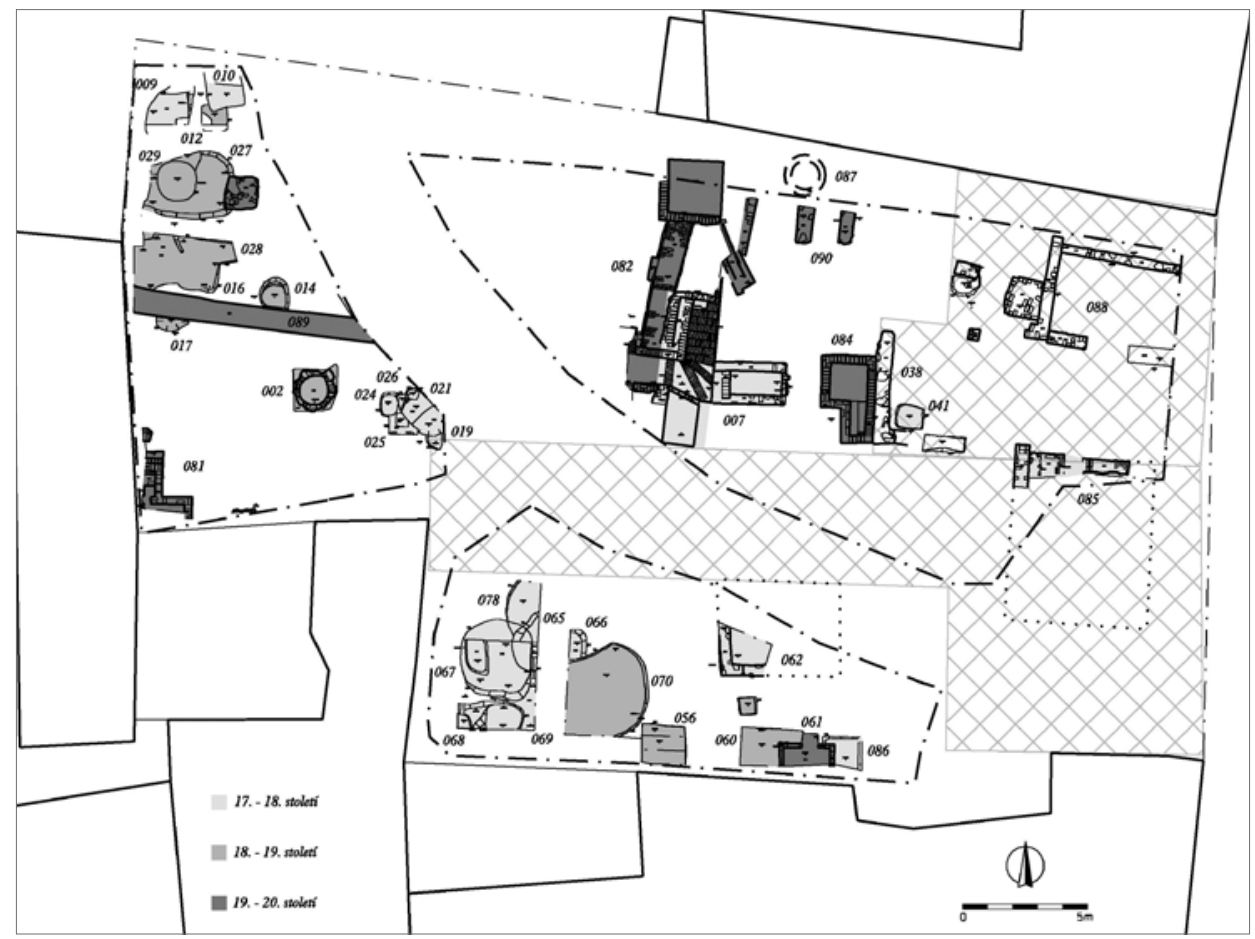

Obr. 21. Přehled zkoumaných situací ze 17.-20. století. Světle šedou barvou podbarveny aktivity 17.-18. století, středně šedou z 18.-19. století, tmavě šedou z 19.-20. století, šrafurou možný rozsah zástavby podle plánu z roku 1825. 007, 062,082, 085 - zděné sklepy; 038, 081, 088-090 - relikty zděných staveb; 002, 087 - studny; 061, 084 - odpadní šachty; 056 - jáma na hašení vápna; 009, 010, 012, 014, 016, 017, 019, 021, 024-029, 041, 060, 065-070, 078, 086 - jámy neznámé funkce.

Abb. 21. Überblick der untersuchten Situationen aus dem 17. bis 20. Jahrhundert. Hellgrau Aktivitäten aus dem 17. bis 18. Jahrhundert, mittelgrau 18. bis 19. Jahrhundert, dunkelgrau 19. bis 20. Jahrhundert. Schraffiert möglicher Umfang der Bebauung laut einem Plan aus dem Jahre 1825. 007, 062, 082, 085 - gemauerte Keller; 038, 081, 088 - 090 Relikte von gemauerten Bauten; 002, 087 - Brunnen; 061, 084 - Abfallschächte; 056 - Grube zur Kalklöschung; 009, 010, 012, 014, 016, 017, 019, 021, 024 - 029, 041, 060, 065 bis 070, 078, 086 - Gruben unbekannter Funktion.

svou dispozici. Nakonec dospěla do podoby, kdy na parcele Vídeňská 6 stál k ulici okapově orientovaný patrový dům s rozsáhlou dvorní zástavbou, na parcele Vídeňská 8 pak rovněž okapově orientovaný, ale přízemní dům s průjezdem v jižní třetině a menší budovou pekárny v zadní části parcely.

Zástavbu parcel doplňovaly další objekty související s jejich provozem a potřebami majitelů. Pitnou vodu zajištovaly v mladším období zděné studny. Studna s. s. j. 002 v zadní části parcely Vídeňská 8 byla vybudována v období 18.-19. století, studna s. s. j. 087 při severní hranici střední partie parcely Vídeňská 6 nebyla blíže datována. Pro starší období situaci neznáme. Přítomnost studní nelze vyloučit. Poměrně blízkým zdrojem vody byla řeka Svratka. Z období 14.-15. století bylo dokumentováno několik jam, které lze interpretovat jako zásobnice. Dvě se nacházely v čelní partii parcely Vídeňská 6 (s. s. j. 043 a 053), jedna na parcele Vídeňská 8 ve vzdálenosti $13 \mathrm{~m}$ od ulice (s. s. j. 058). Snad ke stejnému účelu mohly sloužit také tř́ jámy kruhového půdorysu, jejichž relikty byly dokumentovány v zadní části parcely Vídeňská 6 (s. s. j. 013, 023, 031). Jako odpadní jímky nebyly zcela jednoznačně interpretovány žádné objekty. Velmi pravděpodobně je ale mohly představovat jámy s. s. j. 071 (14. století) a s. s. j. 075 (druhá polovina 15. až 16. století) ve střední části parcely Vídeňská 8 . Zaregistrována byla řada zahloubených objektů blíže neznámé funkce. Většinou se koncentrovaly v zadních částech parcel, zpravidla 
ve vzájemných superpozicích. Často se jednalo o větší jámy oválného či přibližně kruhového půdorysu. Snad mohly původně sloužit jako zdroj hlíny. Většina z nich byla zasypána odpadem s výrazným podílem kuchyňské keramiky z období 17.-19. století.

Jakým způsobem do vývoje zástavby zasahovaly nepříznivé události, přesně nevíme. Na základě archeologických výzkumů jsme většinou schopni postihnout stopy požáru. V tomto ohledu je ovšem výpověd' archeologických pramenů na Vídeňské ulici do jisté míry omezena podmínkami jejich zachování. Ze všech zahloubených objektů nenesl žádný jasné stopy násilného zániku ohněm. Ve výplních nebyly přítomny požárové destrukce. Jedinou výjimkou je pouze svrchní část zásypu suterénu s. s. j. 003. V tomto směru je omezena výpověd' o užitých konstrukcích, která bývá vtisknuta do souborů zlomků vypálené mazanice. Požáry však na základě předeslané situace není možné vyloučit. U zkoumaných zahloubených částí zástavby lze uvažovat o tom, že docházelo zřejmě $\mathrm{k}$ jejich řízenému zániku, nebo - především v případě ražených sklípků - k samovolné destrukci (např. s. s. j. 005, 050, 057, 077).

\section{Závěr}

Archeologický výzkum na parcelách někdejších domů Vídeňská č. 6 a 8 přispěl dílčím způsobem k poznání nejstarší historie a charakteru vrcholně středověkého osídlení na pravém břehu Svratky, které náleželo ke Starému Brnu. K ucelenějšímu pohledu povede cesta přes komplexní vyhodnocení všech dosavadních výzkumů, které dosud nebyly náležitě publikovány.

Dokumentované objekty rozšiřily pramennou základnu týkající se problematiky nezděné zástavby historických parcel. Z brněnské oblasti (vlastního města, jeho historických předměstí a sousedních osad) byl díky soustavnému archeologickému výzkumu získán soubor čítající několik stovek situací, který poskytuje určité možnosti k řešení řady otázek spojených s tímto tématem. Nabízí se srovnání poměrů na jednotlivých lokalitách. Výběrovým způsobem byl $\mathrm{v}$ tomto směru učiněn pokus na stránkách tohoto příspěvku. Poznatky z Vídeňské ulice byly porovnány se situací ve městě a $\mathrm{v}$ Králově Poli. K upřesnění povede podrobná analýza dosud nepublikovaných výzkumů (z Králova Pole především výzkum na Božetěchově ulici 1-3 - akce č. A101/2004, na Mojmírově náměstí 6 - akce č. A7/2009; z předměstí - akce č. A1/2013, z Vídeňské ulice rozsáhlé odkryvy na parcelách někdejších domů č. 18, 20 a 22) a rovněž výsledky budoucích výzkumů (např̀. v době sestavování prŕíspěvku probíhající výzkum na parcele domu Vídeňská 16 - akce č. A32/2017 či chystaná akce na parcele Vídeňská 2).

V tomto ohledu se výzkum na parcelách domů Vídeňská 6 a 8 podílí na postupném dosažení vyváženosti informací získaných z předměstské oblasti vůči zatím nepoměrně rozsáhlejší kolekci poznatků z prostoru města. Díky vyšší míře poznání proto věnovalo dosavadní bádání větší a systematičtější pozornost městu (z hlediska problematiky nezděné architektury naposledy Holub a kol. 2005, tam další literatura). K naplnění vytčeného úkolu vede v první řadě úsilí o rozšíření pramenné základny prostřednictvím terénních archeologických výzkumů. Jako nezbytná součást musí následovat zpracování a publikování dosažených výsledků. Na tomto poli bylo učiněno pouze několik dílčích kroků (např. Zůbek 2016a; 2017) včetně předloženého př́íspěvku. Je tedy velkým závazkem do budoucna $\mathrm{v}$ těchto krocích pokračovat a následně je zapojit do rozsáhlejší syntézy.

Článek byl vytvořen v rámci projektu GAČR reg.č. 17-23836S - „Proměna městského domu ve 13. století“.

\section{Prameny a literatura}

ČERNÁ a kol., 2012: Černá, L.-Dejmal, M.-Holub, P.-Kolařík, V.-Merta, D.-Peška, M.-Sedláčková, L.Zbranek, H.-Zůbek, A., Brno (okr. Brno-město), PV 53, č. 2, 100-136. 
ČERNÁ a kol., 2014: Černá, L.-Holub, P.-Kolařík, V.-Merta, D.-Peška, M.-Sedláčková, L.-Zůbek, A., Brno (okr. Brno-město), PV 55, č. 2, 171-205.

ČERNÁ, L.-SEDLÁČKOVÁ, L., 2016: „Bytový dům Vídeňská, II. etapa, Brno“. Nálezová zpráva č. 18/16, ulož. v archivu společnosti Archaia Brno, o.p.s.

- 2016a: „Bytový dům Vídeňská, III. etapa, Brno“. Nálezová zpráva č. 19/16, ulož. v archivu společnosti Archaia Brno, o.p.s.

ČERNÁ, L.-ZŮBEK, A., 2015: Nálezová zpráva o provedení záchranného archeologického výzkumu při stavbě „Bytový dům Kopečná-Studánka“ k. ú. Staré Brno, p.č. 1149/3. Nálezová zpráva č. 16/14, ulož. v archivu společnosti Archaia Brno, o.p.s.

- 2017: Brno, Vídeňská 6-8. Nálezová zpráva č. 14/16, ulož. v archivu společnosti Archaia Brno, o.p.s.

DOLEŽEL, J., 2000: K městskému zřízení na středověkém Brněnsku do roku 1411 - Zur mittelalterlichen Stadtverfassung in der Brünner Gegend bis 1411, Mediaevalia archaeologica 2, 159-259.

DŘÍMAL, J., 1973: Z dějin brněnských předměstí. In: Dějiny města Brna 2 (Dřímal, J.-Peša, V., red.), 255-319. Brno.

FLODROVÁ, M., 1997: Brněnské ulice a vývoj jejich názvů od 13. století po dnešek. Brno.

FLODROVÁ, M.-MÜLLER, Z., 2007: Staré Brno. Vyprávění o minulosti nejstarší části města Brna. Brno. FOLTÝN, D. a kol., 2005: Encyklopedie moravských a slezských klášterů. Praha.

HOLUB, P. a kol., 2004: Holub, P.-Kolařík, V.-Kováčik, P.-Merta, D.-Peška, M.-Procházka, R.-Zapletalová, D.-Zůbek, A., Systematický archeologický výzkum města Brna, Forum urbes medii aevi I., 57-97.

HOLUB, P. a kol., 2005: Holub, P.-Kolařík, V.-Merta, D.-Peška, M.-Zapletalová, D.-Zůbek, A., Ke stavu poznání nezděné měšt’anské architektury vrcholně středověkého Brna, Forum urbes medii aevi II., 44-101.

HOLUB, P. a kol., 2006: Holub, P.-Kolařík, V.-Merta, D.-Peška, M.-Polánka, P.-Sedláčková, L.-Zapletalová, D.-Zůbek, A., Brno (okr. Brno-město), PV 47, 170-226.

- 2007: Holub, P.-Kolařík, V.-Merta, D.-Peška, M.-Polánka, P.-Sedláčková, L.-Zapletalová, D.-Zůbek, A., Brno (okr. Brno-město), PV 48, 410-461.

HOLUB, P. a kol., 2008: Holub, P.-Kolařík, V.-Merta, D.-Peška, M.-Polánka, P.-Sedláčková, L.-Zapletalová, D.-Zůbek, A., Brno (okr. Brno-město), PV 49, 356-393.

HOLUB, P.-SEDLÁČKOVÁ, L., 2005: Brno - Královo Pole, Božetěchova 1-3. Výstavba areálu FIT VUT Brno. Nálezová zpráva č. 27/05, ulož. v archivu společnosti Archaia Brno, o.p.s.

JAN, L., 2004: Ves a klášter ve středověku (1240-1526). In: Řepa, M. a kol.: Dějiny Králova Pole, 26-69. Brno.

KOLAŘÍK, V. a kol., 2016: Kolařík, V.-Merta, D.-Peška, M.-Sedláčková, L.-Staněk, P.-Zůbek, A., Brno (okr. Brno-město), PV 57, č. 2, 253-269.

KOLAŘÍK, V.-MERTA, D.-ZŮBEK, A., 2014: Archeologická topografie levobřeží Svratky v prostoru Starého Brna, Forum urbes medii aevi VIII., 112-125.

KOS, P., 2002: Výzkum lochů na Moravě. Rukopis magisterské diplomové práce, ulož. v ÚAM FF MU Brno.

- 2005: K moravským lochům, Forum urbes medii aevi II., 166-183.

KUČA, K., 2000: Brno. Vývoj města, předměstí a připojených vesnic. Praha - Brno.

KUNZ, L., 1965: Historické zprávy o zemních silech v zóně mediteránního a eurosibiřského obilnářství, ČMM L, 143-182.

- 2004: Obilní jámy. Konzervace obilí na dlouhý čas v historické zóně eurosibiřského a mediteránního rolnictví. Rolnictví na východní Moravě od baroka do II. světové války, svazek 1. Rožnov pod Radhoštěm.

MATĚJÍČKOVÁ, A., 1999: Brno 1999 - konvent milosrdných bratří. Nálezová zpráva č. 213/99, ulož. v archivu Ústavu archeologické památkové péče Brno.

MERIAN, M., 1650: Topographia Bohemiae, Moraviae et Silesiae, das ist, Beschreibung und eigentliche Abbildung der Vornehmsten und bekandtesten Stätte und Plätze in dem Königreich Boheim und einverleibten Ländern, Mähren und Schlesien“. Frankfurt. Použit exemplář uložený v Moravské zemské knihovně v Brně pod číslem ST3-0035.392.

MERTA, D.-SEDLÁČKOVÁ, L., 2013: Druhá starobrněnská rotunda, VVM LXV, 27-34.

NERUDOVÁ, Z., 2016: Lovci posledních mamutů na Moravě. Brno.

POLÁČKOVÁ, H., 2006: Zahloubené sklepy ve spraši, lochy a další vybrané středověké objekty z areálu zaniklého kláštera na Božetěchově ulici. Rukopis bakalářské diplomové práce, ulož. v ÚAM FF MU Brno.

POLÁNKA, P.-SEDLÁČKOVÁ, L.-ZŮBEK, A., 2006: Brno, Vídeňská 15 (Integrovaný dům). Nálezová zpráva č. 35/06, ulož. v archivu společnosti Archaia Brno, o.p.s.

- 2006a: Brno - Královo Pole. Mojmírovo náměstí 15a. Stavba budovy Výzkumného ústavu vodohospodářského T. G. Masaryka. Nálezová zpráva č. 33/06, ulož. v archivu společnosti Archaia Brno, o.p.s. 
PROCHÁZKA, R.-KOLAŘÍK, V.-ZŮBEK, A., 2013: Předměstí. In: Dějiny Brna 2. Středověké město (Jan, L., red.), 568-600. Brno.

PROCHÁZKA, R.-WIHODA, M.-ZAPLETALOVÁ, D., 2011: V raném středověku. In: Dějiny Brna 1. Od pravěku k ranému středověku (Procházka, R., red.), 447-560. Brno.

SEDLÁČKOVÁ, L., 2012: „Bytový dům Vídeňská - inženýrské sítě“. Nálezová zpráva č. 10/12, ulož. v archivu společnosti Archaia Brno, o.p.s.

- 2012a: Stavba SO 06 prodloužení horkovodu a SO 15 př́ípojka horkovodu pro SO 01 „Obytný soubor Brno, Vídeňská, domy A+B“. Nálezová zpráva č. 25/11, ulož. v archivu společnosti Archaia Brno, o. p. s.

SMÍŠEK, K., 2018: Numismatické určení souboru mincí z archeologického výzkumu společnosti Archaia o.p. s. na lokalitě Brno, Vídeňská 6-8 (A 113/2012). Velké Př́lepy. Rkp. ulož. v archivu společnosti Archaia Brno, o.p.s.

URBÁNKOVÁ, K.-ZAPLETALOVÁ, D., 2003: Polní ulice - předchůdkyně císařské silnice? Průběh tzv. mikulovské, respektive vídeňské cesty pravobřežním Starého Brna, BMD 17, 79-96, 564-568.

ZAPLETALOVÁ, D., 1999: Brno, Milosrdní bratř́i. Nálezová zpráva č. 5/99, ulož. v archivu společnosti Archaia Brno, o.p.s.

- 2005: Brno, Nemocnice Milosrdných bratří, Pavilon akutní medicíny - 1. etapa. Nálezová zpráva č. 1/, ulož. v archivu společnosti Archaia Brno, o. p.s.

- 2009: Starobrněnské pravobřežní Svratky v raném středověku. In: Archeologie doby hradištní v České a Slovenské republice. Archaeologia mediaevalis Moravica et Silesiana. Supplementum 2 (Dresler, P.Měřínský, Z., edd.), 192-210. Brno.

ZAPLETALOVÁ, D.-HLOŽEK, M., 2010: Vážky z Polní ulice na Starém Brně - Balance scale from Polní Street in Staré Brno, AR LXII, 137-149.

ZŮBEK, A., 2016: Hřbitov při kostele sv. Jakuba v Brně. Vyhodnocení archeologických poznatků. Brno.

- 2016a: Vývoj historické zástavby parcely č. 1149/3 při Kopečné ulici v Brně - Die historische Entwicklung der Bebauung von Parzelle Nr. 1149/3 an der Brünner Straße Kopečná, AH 41, 345-362.

- 2017: Vývoj historické zástavby parcely někdejšího domu č. 24 na Kopečné ulici v Brně - Die Entwicklung der historischen Bebauung auf der Parzelle des ehemaligen Hauses Nr. 24 in der Straße Kopečná in Brno, AH 42, 71-93.

\section{Zusammenfassung}

\section{Archäologische Erscheinungsformen der mittelalterlichen und frühneuzeitlichen mauerlo- sen Bebauung auf den Parzellen der ehemaligen Häuser Nr. 6 und 8 in der Vídeňská-Straße in Brünn}

Der vorliegende Beitrag fasst die Erkenntnisse über die mittelalterliche und frühneuzeitliche Bebauung auf den Parzellen der ehemaligen Häuser Nr. 6 und 8 in der Brünner Vídeňská-Straße zusammen, die offenbar vor allem aus mauerlosen Bauten (Holz oder Holz-Lehmbauten) bestand. Ihre archäologisierten Überreste wurden im Rahmen einer Rettungsgrabung untersucht, die im Jahr 2013 von der Gesellschaft Archaia Brno durchgeführt wurde. Die einzelnen Objekte werden beschrieben und anhand von zuverlässigen Merkmalen in entsprechende Gruppen kategorisiert. Es wurde ein Grundvergleich mit archäologischen Erscheinungsformen einer Holz-Lehm-Bebauung durchgeführt, die sich an weiteren Fundstellen des engeren Brünner Raums befinden; vor allem in der Stadt selbst, in ihrer Vorstadt und im ehemaligen Dorf Královo Pole, das sich durch enge Beziehungen auszeichnete, durch welche sich Vorstädte ausweisen.

Die Parzellen in der heutigen Vídeňská-Straße gehörten zu einer (ungefähr $1 \mathrm{~km}$ von der Stadt entfernten) Siedlung, die sich entlang einer Ferntrasse gebildet hat, welche die Region Brünn mit Österreich verbindet. Sie war Teil von Altbrünn, dem Machtzentrum des 11. und 12. Jahrhunderts, das sich zu einem Gebilde transformierte, das man als Untertanenstädtchen bezeichnen könnte. Die entsprechenden Parzellen gehörten zu dessen südlich gelegenen Partie am rechten Ufer des Flusses Svratka. Die dortige Bebauung wurde erstmals im ikonographischen Material aus der Mitte des 17. Jahrhunderts abgebildet. Der Verlauf ihrer Entwicklung lässt sich bis zu einem gewissen Grad auf Plänen des anschließenden 18. bis 20. Jahrhunderts beobachten. 
Die archäologische Grabung wurde stark durch die Vorgehensweise des Bauherren eingeschränkt. Das archäologische Vorhaben kann man als auf den entsprechenden Parzellen erfolgte Vorlauf-Sondierungsgrabung bezeichnen, deren archäologische Gesamtfreilegung nicht durchgeführt werden konnte. Die Baustelle hatte das Ausmaß von $1000 \mathrm{~m}^{2}$. Die archäologische Freilegung spielte sich auf drei Einzelflächen im Gesamtausmaß von $600 \mathrm{~m}^{2} \mathrm{ab}$. Bei einigen der tiefsten Aushebungen wurde das untere Niveau nicht untersucht.

Die Erscheinungsformen der mittelalterlichen und frühneuzeitlichen Bebauung beschränkten sich nur auf ihre deutlich eingetieften Teile. Außer möglichen Relikten der oberirdischen Gebäudepartien (etwa Fußbodenschichten) fehlten auch eventuelle Belege für die eingetieften Teile ihrer oberirdischen Konstruktionen (etwa Pfeiler- oder Pfahlgruben, Rinnen zum Setzen der Fundamentbalken). Registriert wurden dreizehn Situationen, die man mit einer mauerlosen Bebauung in Verbindung bringen kann. Sie lassen sich in drei Grundgruppen unterteilen: Souterrains (Keller), Kellergruben/Vorratsgruben (gegrabene Objekte), ausgehobene Kellergruben (durch Aushebung des Unterbodens gebildete Objekte). Ihre Datierung erfolgte anhand einer Analyse der stratigraphischen Situation und des aus der Verfüllung gewonnenen Materials. Meistens handelte es sich dabei um Bruchstücke von Keramikgefäßen, was in einigen Fällen um Münzfunde ergänzt wurde.

Die genaue bauliche Entwicklung der Parzellen lässt sich anhand der durch die archäologische Grabung gewonnenen Ergebnisse nicht rekonstruieren. Die älteste hochmittelalterliche Situation kann in den Zeitraum zweite Hälfte 13. bis 14. Jahrhundert datiert werden. Eine Besiedelung aus der ersten Hälfte des 13. Jahrhunderts lässt sich freilich nicht ganz ausschließen. Die Nutzung der Parzellen wurde offenbar kontinuierlich bis ins 20. Jahrhundert fortgesetzt. Die gewonnenen Erkenntnisse deuten darauf hin, dass das Grundstück bereits ab dem Mittelalter in zwei Parzellen unterteilt war. Der Hauptteil der Bebauung befand sich an ihrer Vorderseite an der Straßenfront. Dies wurde durch die Situation auf der Parzelle des Hauses Vídeňská-Str. Nr. 6 klar nachgewiesen. Bereits für den ältesten Zeitraum sind dort drei mauerlose Souterrains belegt, die sich in einer zeitlich aufeinanderfolgenden Superposition befanden. Die entsprechenden Häuser hatten offenbar vor allem eine Wohnfunktion. Es konnte selbstverständlich auch zu einer Mehrzwecknutzung gekommen sein. Die Anlage der Häuser lässt sich nicht genau bestimmen.

Eine gemauerte Bebauung kommt offenbar erst in der Neuzeit auf. Die ältesten dokumentierten Keller lassen sich in die Zeit des 17. bis 18. Jahrunderts legen. Die Frage ist, ob die zu diesen Kellern gehörende Bebauung ebenfalls Mauern hatte. Wahrscheinlich konnte es (vor allem im vorhergehenden Zeitraum) zu einer kombinierten Verwendung des Baumaterials gekommen sein, sodass gemauerte Gebäude und Holzbauten nebeneinander stehen konnten. In der jüngeren Zeit vermissen wir jedoch bereits Souterrains und Kellergruben, die nicht gemauert gewesen wären. In der jüngsten Phase war die Bebauung ausschließlich gemauert. So wurde sie auf einer Indikationsskizze aus dem Jahre 1825 dargestellt. Auf weiteren Plänen aus dem 19. Jahrhundert kann die bauliche Entwicklung der Bebauung relativ gut verfolgt werden. Aus ihnen wird klar ersichtlich, dass sich ihrer Anlage mehrmals veränderte. Schließlich hatte sie die Form, die sie erhielt, als auf der Parzelle Vídeňská-Str. Nr. 6 ein zweistöckiges, traufständiges Haus mit ausgedehnter Hofbebauung und auf der Parzelle Vídeňská-Str. Nr. 8 ebenfalls ein traufständiges, jedoch einstöckiges Haus mit Einfahrt zum südlichen Drittel und einem kleineren Bäckereigebäude im hinteren Parzellenteil stand.

Die Bebauung der Parzellen wurden um weitere, mit ihrem Betrieb und den Bedürfnissen der Besitzer zusammenhängenden Objekten ergänzt. Die Trinkwasserversorgung erfolgte in der jüngeren Zeit durch gemauerte Brunnen. Für die älteren Zeiträume ist die Situation unbekannt. Das Vorhandensein von Brunnen kann nicht ausgeschlossen werden. Eine verhältnismäßig nahe Wasserquelle war der Fluss Svratka. Aus der Zeit des 14. bis 15. Jahrhunderts wurden mehrere Gruben dokumentiert, die als Vorratsgruben interpretiert werden können. Völlig eindeutig als Abwassergruben wurden keine Objekte interpretiert. Sehr wahrscheinlich können jedoch zwei Gruben aus dem 14. Jahrhundert und der zweiten Hälfte des 15. bis 16. Jahrhunderts solche Abwassergruben darstellen. Registriert wurde auch eine Reihe eingetiefter Objekte von nicht 
näher bekannter Funktion. Die meisten waren im hinteren Teilen der Parzellen konzentriert, in der Regel in gemeinsamen Superpositionen. Häufig handelte es sich dabei um größere Gruben mit ovalem oder annähernd rundem Grundriss. Möglicherweise haben sie ursprünglich als Lehmgruben dienen können. Die meisten von ihnen waren mit Abfall zugeschüttet, der einen deutlichen Anteil an Küchenkeramik aus der Zeit des 17. bis 19. Jahrhunderts enthielt.

Der vorliegende Beitrag entstand im Rahmen des Förderprojektes GAČR Reg.-Nr. 17-23836S - „Der Wandel des Stadthauses im 13. Jahrhundert“.

Mgr. Antonín Zůbek, Ph.D., Archaia Brno, o. p. s., Bezručova 15, 60200 Brno, Česká republika, azubek@archaiabrno.cz 
